|ㅣ|||||||||||

Post-Closure Inspection and Monitoring Report for Corrective Action Unit 417: Central Nevada Test Area Surface, Hot Creek Valley, Nevada

January 2009 
This page intentionally left blank 


\section{Post-Closure Inspection and Monitoring Report for Corrective Action Unit 417: Central Nevada Test Area Surface, Hot Creek Valley, Nevada}

January 2009 
This page intentionally left blank 


\section{Contents}

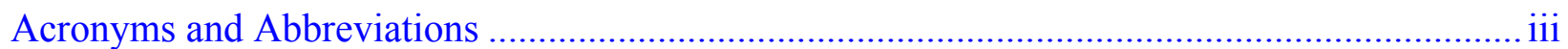

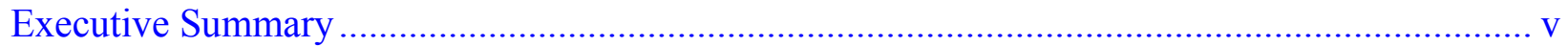

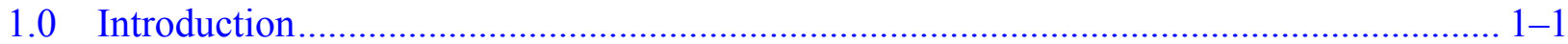

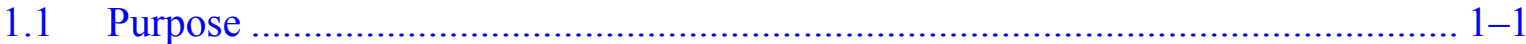

1.2 Site Location and Background............................................................................ 1-1

1.3 Geologic Setting .......................................................................................... 1-2

2.0 Post-Closure Monitoring Requirements ……………................................................... 2-1

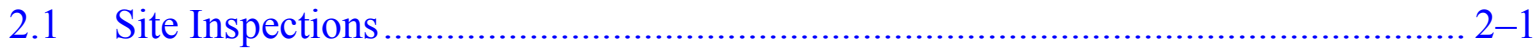

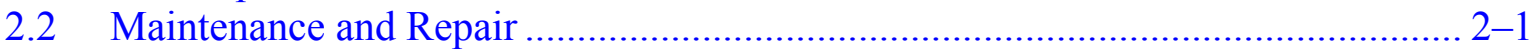

2.3 Soil Moisture Monitoring .......................................................................... 2-2

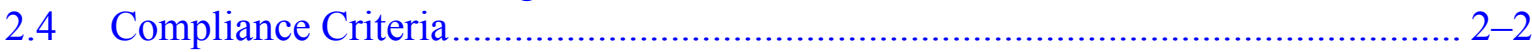

2.5 Reporting Requirements .......................................................................... 2-4

3.0 Site Inspections, Surveys, and Maintenance ................................................................. 3-1

3.1 Annual Site Inspection Results ................................................................... 3-1

3.1.1 UC-1 Inspection........................................................................... 3-1

3.1.2 UC-3 Inspection......................................................................... 3-1

3.1.3 UC-4 Inspection............................................................................ 3-1

3.2 Subsidence Survey Results ............................................................................ 3-1

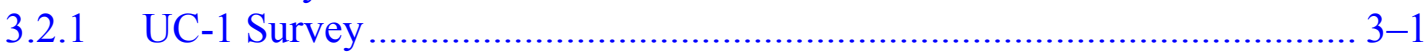

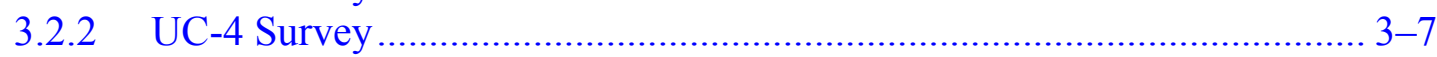

3.3 Vegetation Survey Results.......................................................................... 3-9

3.4 Precipitation and Soil Moisture Monitoring Results ............................................... 3-9

3.4.1 UC-1 Soil Moisture Results.................................................................... 3-9

4.0 Summary, Conclusions, and Recommendations......................................................... 4-1

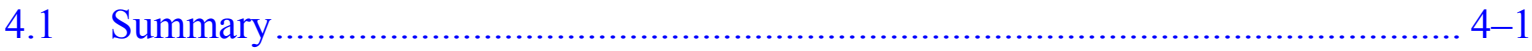

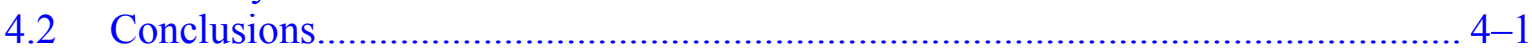

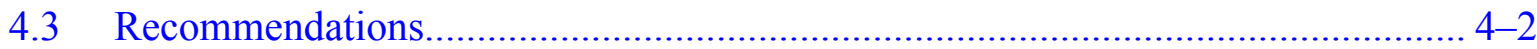

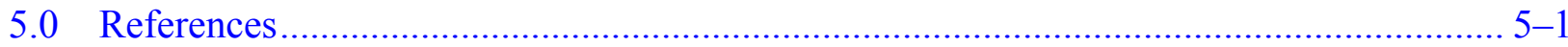

\section{Figures}

Figure 1-1. Central Nevada Test Area Location Map ............................................................. 1-2

Figure 1-2. CAU 417, Central Nevada Test Area Surface Map ............................................. 1-3

Figure 2-1. UC-1 CMP Cover Monitoring Instrumentation ................................................ 2-3

Figure 3-1. Location of UC-1 Mud Pits A and E ............................................................. 3-2

Figure 3-2. Location of UC-4 Mud Pits A, B, D, S, and X................................................ 3-3

Figure 3-3. UC-1 Cover Settlement …………......................................................... 3-4

Figure 3-4. UC-4 West and East Monuments ................................................................. 3-7

Figure 3-5. UC-4 Cover Settlement ……………..................................................... 3-9

Figure 3-6. July 1, 2007 through June 1, 2008 Precipitation Data......................................... 3-10

Figure 3-7. UC-1 Soil Moisture Content, East TDR Nest A................................................. 3-10

Figure 3-8. UC-1 Soil Moisture Content, East TDR Nest B .................................................. 3-11

Figure 3-9. UC-1 Soil Moisture Content, West TDR Nest A ................................................ 3-12

Figure 3-10. UC-1 Soil Moisture Content, West TDR Nest B ................................................ 3-12 


\section{Tables}

Table 3-1. UC-1 Monument Elevations and Subsidence ................................................... 3-5

Table 3-2. UC-4 Monument Elevations and Subsidence ..................................................... 3-8

\section{Appendixes}

Appendix A Inspection Checklists and Photographs

Appendix B NDEP Correspondence 


\section{Acronyms and Abbreviations}

$\begin{array}{ll}\text { CAU } & \text { Corrective Action Unit } \\ \mathrm{cm} & \text { centimeter(s) } \\ \text { CMP } & \text { Central Mud Pit } \\ \text { CNTA } & \text { Central Nevada Test Area } \\ \text { LM } & \text { U.S. Department of Energy Office of Legacy Management } \\ \text { FFACO } & \text { Federal Facility Agreement and Consent Order } \\ \mathrm{ft} & \text { foot (feet) } \\ \text { in. } & \text { inch(es) } \\ \text { km } & \text { kilometer(s) } \\ \text { m } & \text { meter(s) } \\ \text { mi } & \text { mile(s) } \\ \text { NDEP } & \text { Nevada Division of Environmental Protection } \\ \text { SOARS } & \text { System Operation and Analysis at Remote Sites } \\ \text { SM } & \text { Subsidence Monument } \\ \text { TDR } & \text { Time Domain Reflectometry } \\ \text { VMC } & \text { Volumetric Moisture Content }\end{array}$


This page intentionally left blank 


\section{Executive Summary}

This report presents data collected during the annual post-closure site inspection conducted at the Central Nevada Test Area Surface Corrective Action Unit (CAU) 417 in May of 2008. The annual post-closure site inspection included inspections of the UC-1, UC-3, and UC-4 sites in accordance with the Post-Closure Monitoring Plan provided in the CAU 417 Closure Report (NNSA/NV 2001).

The annual inspection conducted at the UC-1 Central Mud Pit (CMP) indicated that the site and soil cover were in good condition. Three new cracks or fractures were observed in the soil cover during the annual inspection and were immediately filled with bentonite chips. The vegetation on the soil cover was adequate, but showed signs of the area's ongoing drought. No issues were identified with the CMP fence, gate, or subsidence monuments. No issues were identified with the warning signs and monuments at the other two UC-1 locations.

The annual subsidence survey was conducted at UC-1 CMP and UC-4 Mud Pit C in August 2008. The results of the subsidence surveys indicate that the covers are performing as expected, and no unusual subsidence was observed.

A vegetation survey of the UC-1 CMP cover and adjacent areas was not performed this year. The next vegetation survey is scheduled for 2009 .

Precipitation occurring July 1, 2007 to June 30, 2008 was below average; the total rainfall for this period was 1.52 millimeters (0.06 inches). Soil moisture content data showed that the UC-1 CMP cover is performing as designed, and evapotranspiration is effectively removing water from the cover.

The inspection at UC-3 indicated that the site is in good condition. All monuments and signs showed no displacement, damage, or have not been removed. No other issues or concerns were identified.

The inspection at UC-4 indicated that the site is in good condition. All monuments and signs showed no displacement, damage, or have not been removed. 
This page intentionally left blank 


\subsection{Introduction}

This report presents data collected during the annual post-closure site inspection conducted by the U.S. Department of Energy (DOE) Office of Legacy Management (LM) at the Central Nevada Test Area (CNTA) surface Corrective Action Unit (CAU) 417. This report has been prepared in accordance with the Post-Closure Monitoring Plan contained in the CAU 417 Closure Report (NNSA/NV 2001) and Federal Facility Agreement and Consent Order (FFACO) (FFACO 1996). Responsibility for environmental site restoration of the CNTA was transferred from the DOE Office of Environmental Management to LM on October 1, 2006.

This report provides an analysis and summary of the annual site inspection and subsidence survey, meteorological information, and soil moisture monitoring data collected since the last annual inspection in May 2007. In 2008, the annual site inspection was conducted to document the physical condition of the CAU 417 soil covers, monuments, signs, fencing, and restricted-use areas. Subsidence surveys of the UC-1 Central Mud Pit (CMP) and UC-4 Mud Pit C covers were also conducted. In addition, the UC-1 CMP cover is instrumented to monitor the soil moisture conditions within the upper 1.2 meters $(\mathrm{m})$ (4 feet [ft]) of the cover to determine if the cover is performing as designed.

\subsection{Purpose}

The purpose of the post-closure monitoring at CAU 417 is to determine if:

- Maintenance or repairs to the UC-1 CMP or UC-4 Mud Pit C cover, fences, or diversion channels are needed;

- $\quad$ UC-1 CMP or UC-4 Mud Pit C covers are subsiding;

- UC-1 CMP cover is performing as designed;

- Maintenance and repair to the aboveground monuments or warning signs at UC-1, UC-3, and UC-4 are needed; and

- $\quad$ Modifications to the administrative controls are needed.

\subsection{Site Location and Background}

The CNTA is located approximately 22.5 kilometers $(\mathrm{km})(14$ miles [mi]) north of U.S. Highway 6 and approximately $137 \mathrm{~km}(85 \mathrm{mi})$ northeast of Tonopah in Nye County, Nevada (Figure 1-1). Three emplacement boreholes, UC-1, UC-3, and UC-4, were drilled at CNTA for underground nuclear weapons testing. On January 19, 1968, the Project Faultless

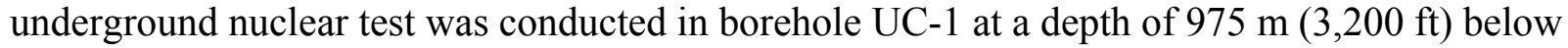
ground surface. The other two emplacement boreholes (UC-3 and UC-4) were not used, and no further testing was conducted at CNTA. Boreholes UC-1, UC-3, and UC-4 are located on three separate land withdrawals that range in size from approximately 1 to 1.5 square mi (Figure 1-2). All three land withdrawals are accessible to the public. 


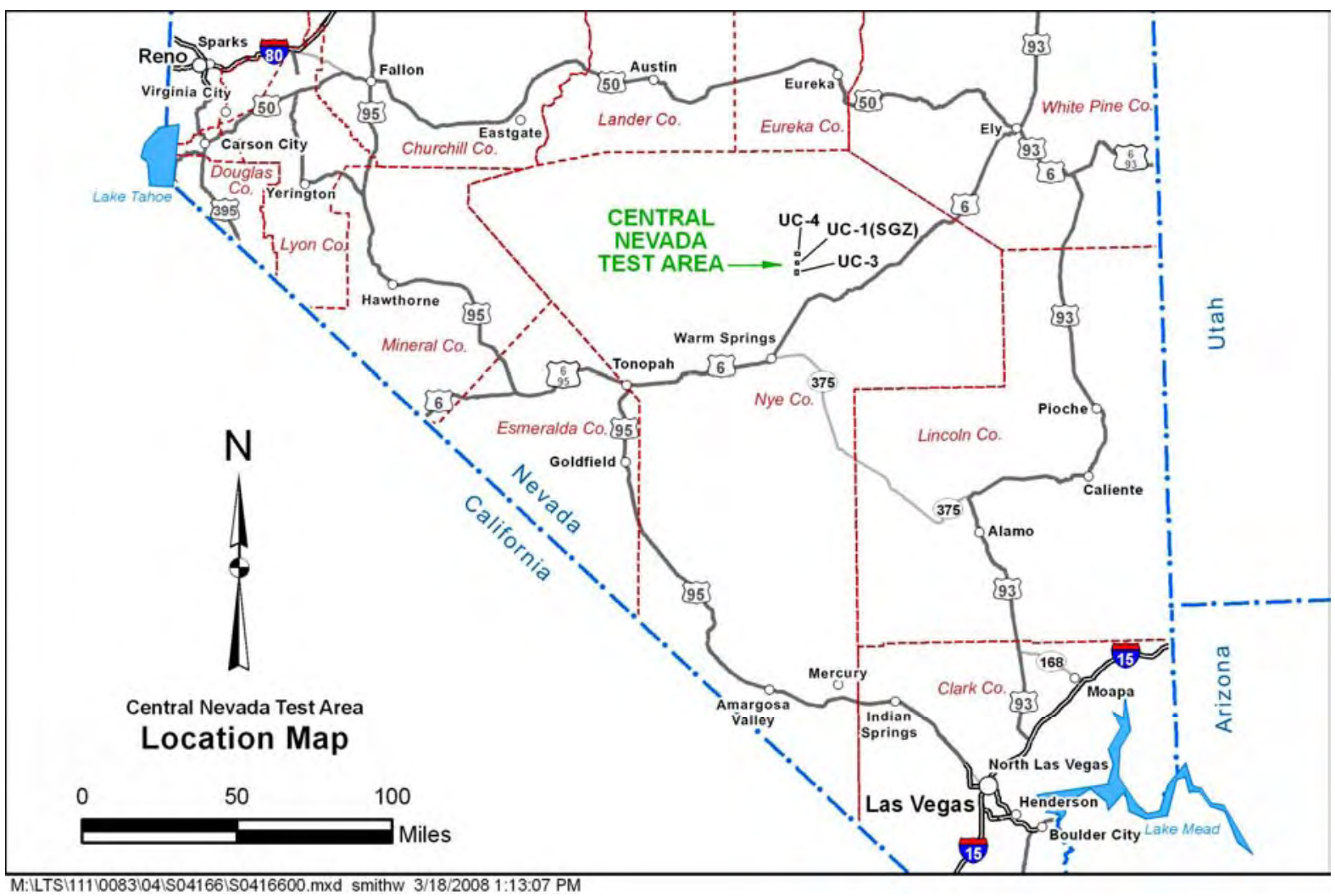

Figure 1-1. Central Nevada Test Area Location Map

\subsection{Geologic Setting}

The CNTA is located in the north-central portion of the Hot Creek Valley within the Basin and Range physiographic province. This province consists of regularly spaced, roughly north-southtrending mountain ranges, separated by alluvial valleys formed by faulting. The UC-1 site lies at an elevation of 1,860 m (6,100 ft) above mean sea level and is bordered by the Hot Creek Range to the west and the Pancake Range to the east. The Hot Creek Range is composed of Paleozoic sedimentary rocks and Tertiary volcanic rocks. The Paleozoic rocks consist of sandstone, quartzite, limestone, and dolomite; while the Tertiary volcanic rocks consist of welded tuff, nonwelded bedded tuff, argillized and zeolitized tuff, conglomeratic tuffaceous sandstone, carbonaceous siltstone, and rhyolite (Healey 1968). The alluvium at UC-1 is approximately $730 \mathrm{~m}(2,400 \mathrm{ft})$ thick and is underlain by tuffaceous sediments and zeolitized tuffs to a depth of

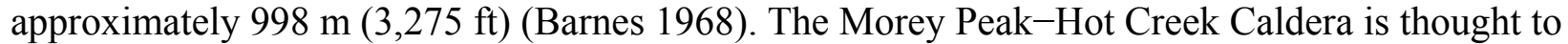
be buried by deposits of tuff and alluvium beneath the northern portion of Hot Creek Valley (Healey 1968).

The Project Faultless test resulted in the subsidence of an irregularly shaped area of approximately 0.9 square kilometer ( 0.3 square mile). One northeast-trending fault scarp extends beneath the southeastern corner of the UC-1 Mud Pit and cover, with as much as $4.6 \mathrm{~m}(15 \mathrm{ft})$ vertical displacement. Normal drainage patterns were disrupted by the formation of this scarp, so flood diversion channels were constructed to protect the cover and prevent infiltration along the fault scarp (NNSA/NV 2001). Depth to the water table at the UC-1 CMP is approximately $168 \mathrm{~m}$ $(550 \mathrm{ft})$. 


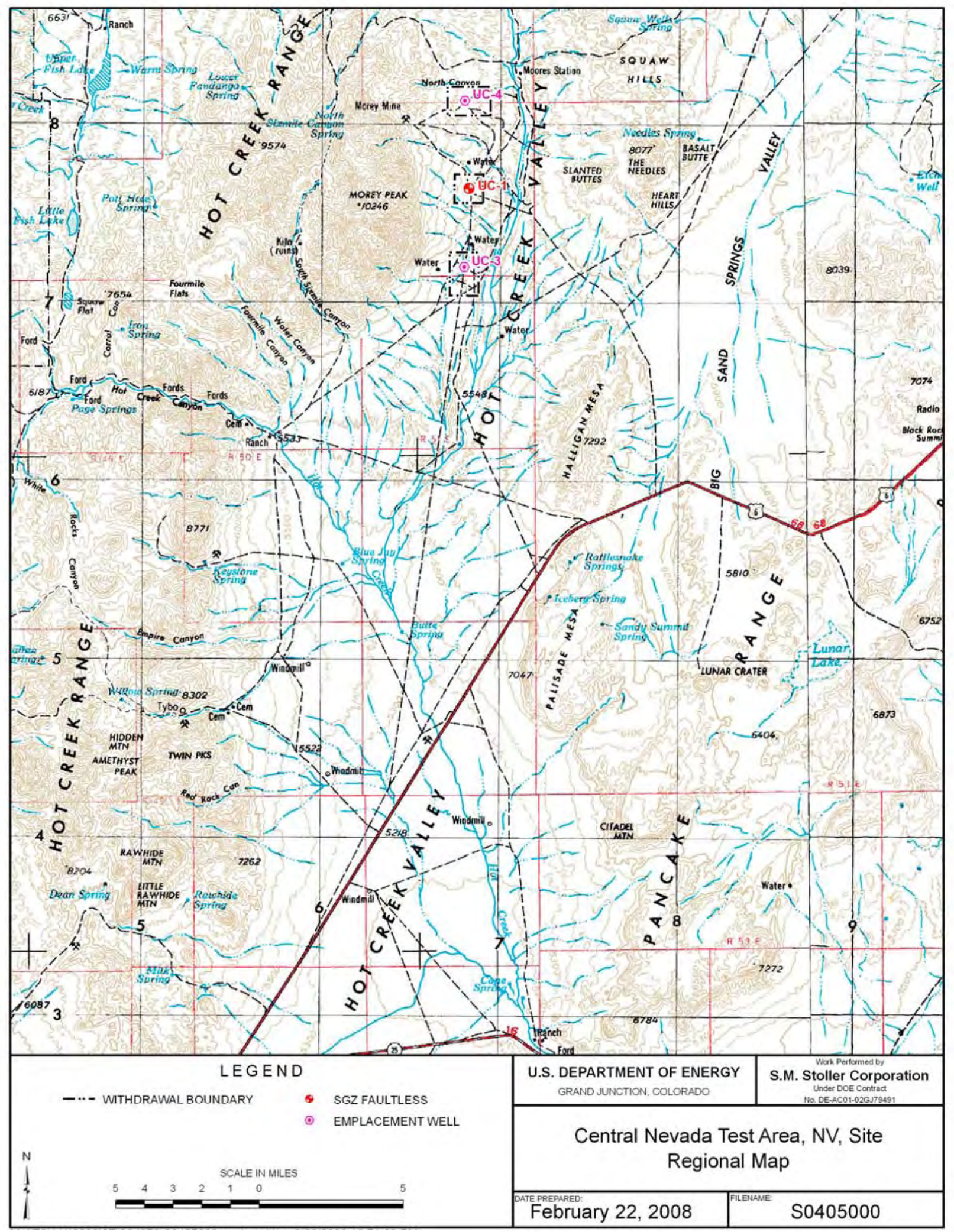

Figure 1-2. CAU 417, Central Nevada Test Area Surface Map 
This page intentionally left blank 


\subsection{Post-Closure Monitoring Requirements}

\subsection{Site Inspections}

Quarterly inspections have been conducted since the closure of the site in 2000. Beginning in 2007, the post-closure inspection of CAU 417 has been performed annually. The annual site inspection is documented on an inspection checklist, with site photographs, and field notes, if applicable. The post-closure inspection consists of the following:

- $\quad$ Inspecting the UC-1 CMP cover and UC-4 Mud Pit C cover and fencing. This includes walking the entire perimeter of the fence and documenting the condition of the barbed and chicken wire fencing, warning signs, and entrance gate.

- $\quad$ Inspecting all aboveground monuments, attached warning signs, and affixed survey pins placed at UC-1, UC-3, and UC-4 sites for signs of wear, disturbance, vandalism, animal burrows, and other damage. Repairing monuments and attached signs during site inspection visits, or if necessary, at a later time in the calendar year.

- Inspecting the condition of the 2 subsidence monuments (SMs) on the UC-4 cover and 12 SMs on the UC-1 CMP cover. A subsidence survey of all SMs is conducted annually to determine if the covers have subsided.

- Documenting any changes to the cover or fenced area, including but not limited to, the presence of trash and debris inside the fenced areas, animal burrows on the cover or under the perimeter fence, erosion features on the covers or diversion channels, and any change in the health of the UC-1 CMP cover vegetation.

- $\quad$ Documenting the soil water content profile of the UC-1 CMP cover to evaluate whether it is performing as designed.

- $\quad$ Biannually, reporting on the health and stability of the UC-1 CMP cover vegetation.

\subsection{Maintenance and Repair}

If a site inspection detects that either the UC-1 CMP cover or the UC-4 Mud Pit C cover is not in compliance, or if conditions requiring major repairs are noted, or if any other problems in critical areas are noted, then issues will be evaluated and reported to the Nevada Division of Environmental Protection (NDEP) within 60 days of detection (in compliance with the FFACO). The following guidelines apply to CAU 417 maintenance and repairs:

- $\quad$ Cracks, settling features, erosion rills, and animal burrows larger than 15 centimeters $(\mathrm{cm})$

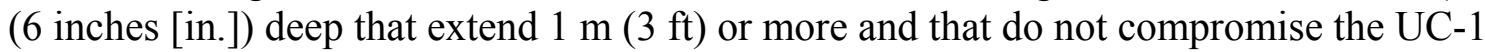
CMP or UC-4 Mud Pit C covers will be evaluated and repaired within 90 days of detection.

- $\quad$ Noncritical cracks, settling features, erosion rills, and animal burrows less than $15 \mathrm{~cm}$

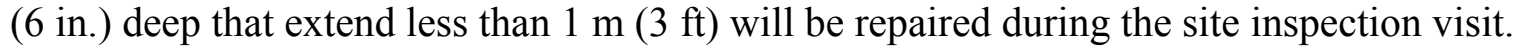

- $\quad$ Damage to the fencing surrounding the UC-1 CMP cover or the UC-4 Mud Pit C cover, warning signs, or monuments will be evaluated and repaired within 90 days of detection.

- $\quad$ Major damage to use-restriction warning signs or monuments will be evaluated and repaired during subsequent site inspections. 
- All repair work will preserve the original as-built design and will be documented in the annual post-closure report.

\subsection{Soil Moisture Monitoring}

The CNTA UC-1 CMP monolayer cover is designed to limit infiltration of moisture into the disposal unit by evapotranspiration from vegetation that was established on the cover. The cover performance is monitored using time domain reflectometry (TDR) sensor data to provide a profile of the water content in the cover. The soil water content profile determines whether the cover is performing as designed and if it is in compliance with the closure plan and agreements.

The soil moisture content is obtained using a Campbell Scientific TDR-100 and recorded by a Campbell Scientific data logger housed in an instrument vault located just off the southern edge of the cover. TDR sensors were buried in the cover at two locations during cover construction. At both locations, two TDR sensors were placed below the surface of the cover at the following depths: $0.15,0.46,0.76$, and $1.07 \mathrm{~m}(0.5,1.5,2.5$, and $3.5 \mathrm{ft})$ (Figure 2-1). The TDR nests are located approximately $48 \mathrm{~m}(157 \mathrm{ft})$ northwest and $48 \mathrm{~m}(157 \mathrm{ft})$ northeast of the instrument vault.

The TDR probes were calibrated to volumetric moisture content (VMC) using a dry-down method with native soil and full-length cable. The results of the calibration indicated that a site-specific calibration equation should be used instead of the standard Topp equation (Topp et al. 1980). It was also found that long cable lengths and soil conductivities caused the TDR reflection end points to become extremely flat under saturated and near-saturated conditions, resulting in unreliable data in these regions.

A fourth-order polynomial fit of the calibration data, over the range of 5 to 35 percent $\mathrm{VMC}$, yielded the following calibration equation:

$$
\operatorname{VMC}(\%)=-308.701+373.1803(\mathrm{~L} / \mathrm{L})-163.644(\mathrm{~L} / \mathrm{L})^{2}+31.82972(\mathrm{~L} / \mathrm{L})^{3}-2.25548(\mathrm{~L} / \mathrm{L})^{4}
$$

Where $\mathrm{L} / \mathrm{L}$ is the ratio of cable length to probe length as recorded by the data logger.

In early October 2008 the UC-1 CMP's existing data logger was replaced with a new Campbell Scientific data logger, CR1000, and a radio to transmit data to an onsite telemetry station, thus eliminating the need for a satellite uplink. Soil moisture data are being recorded twice daily and imported and saved into the System Operation and Analysis at Remote Sites (SOARS) system at LM's Grand Junction office. The post-processing software used by SOARS automatically produces graphs, creates tables, and backs up data daily.

\subsection{Compliance Criteria}

The depth of the deepest TDR soil moisture probe is the point of compliance for the UC-1 CMP cover, which is approximately $1.07 \mathrm{~m}(3.5 \mathrm{ft})$ below ground surface. Cover compliance will be based on the soil moisture content of the cover once steady-state conditions are reached. Cover performance modeling presented in the CAU 417 Corrective Action Plan (DOE/NV 2000) predicted that steady-state conditions will be achieved within 10 years of cover construction, which was completed in September of 2000. At that time, it is expected that soil moisture trigger values will be agreed upon as compliance criteria with NDEP. 


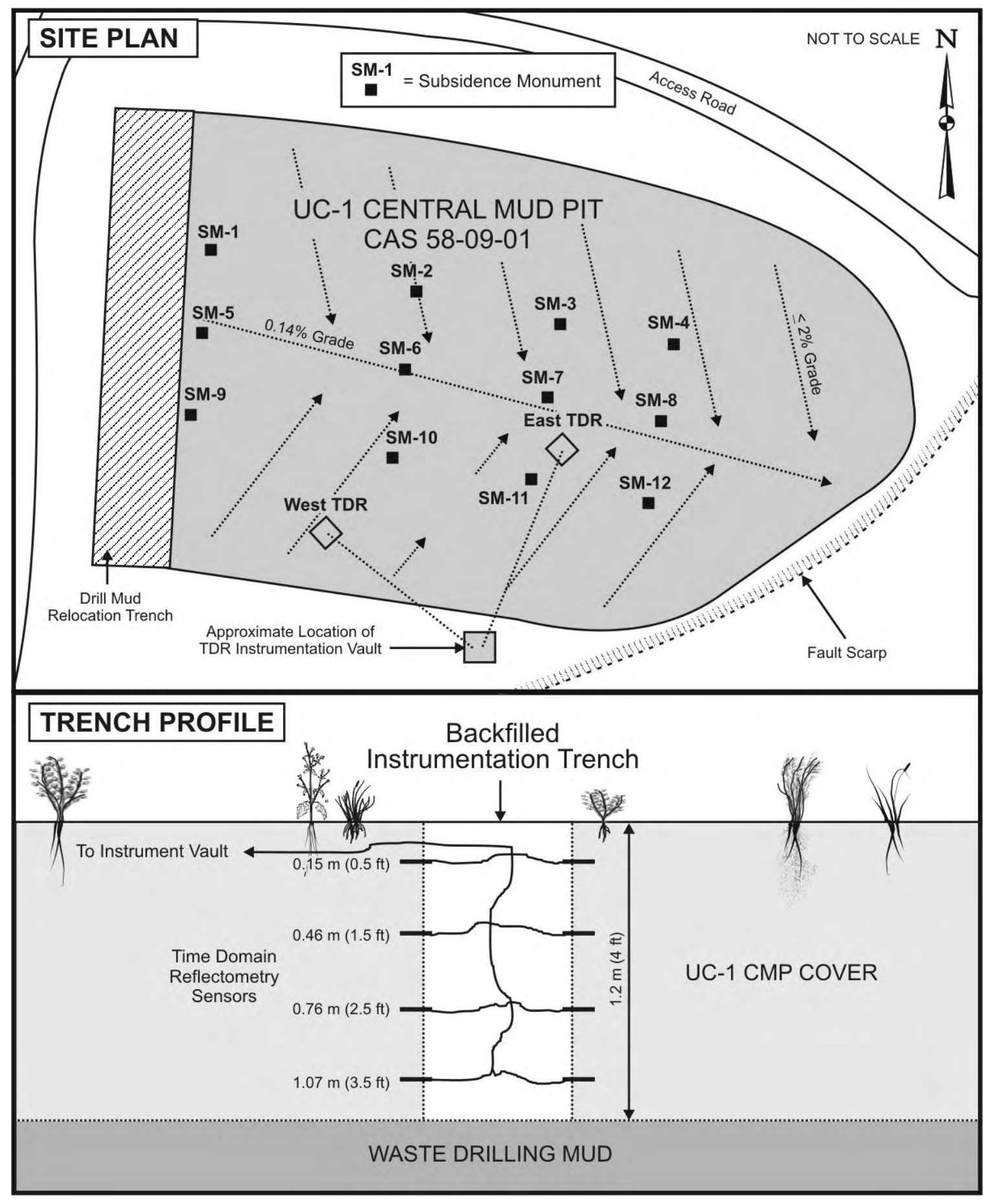

Figure 2-1. UC-1 CMP Cover Monitoring Instrumentation

If soil moisture data indicates that the cover is not operating according to established compliance criteria, NDEP will be notified of the noncompliance within 14 days. After notified of noncompliance, a work plan will be submitted to NDEP within 90 days, outlining the proposed remediation/investigation plan. All corrective actions will be documented in the annual Post-Closure Inspection and Monitoring Report. 


\subsection{Reporting Requirements}

All inspection and maintenance activities conducted during the year are documented and included in an annual Post-Closure Inspection and Monitoring Report. The report is submitted by LM to NDEP and includes the following information:

- A brief narrative and discussion of all post-closure inspection activities and observations;

- $\quad$ Copies of all completed inspection checklists and maintenance records;

- $\quad$ UC-1 CMP soil moisture content profiles from the previous year;

- $\quad$ Subsidence survey data; and

- Specific recommendations for nonstandard maintenance or changes in post-closure requirements.

All closure and post-closure monitoring documentation is maintained in project files and is available upon request. 


\subsection{Site Inspections, Surveys, and Maintenance}

\subsection{Annual Site Inspection Results}

The annual inspection of all three sites was performed on May 13, 2008. The land survey of SMs at UC-1 and UC-4 occurred on August 12, 2008. Copies of the inspection checklists and photographs for CY 2008 are included in Appendix A. A summary of the inspection results is provided in the following sections.

\subsubsection{UC-1 Inspection}

The CMP site was in good condition. All locks, fencing, and signs were in good order. The vegetation on the cover continues to look drought-stressed. No issues were identified with the monuments, and no maintenance or repairs were recommended. All other signs and monuments at Mud Pits A and E (Figure 3-1) were in excellent condition.

Minor maintenance activities were performed at UC-1 in 2008. Three cracks in the cover showing lateral expansion were observed during and repaired at the time of the inspection.

\subsubsection{UC-3 Inspection}

The site was in excellent condition. No issues were identified with the monuments or signs, and no maintenance or repairs were recommended.

No issues or concerns were found during the inspections in 2008; therefore, no maintenance or repairs were performed.

\subsubsection{UC-4 Inspection}

The Mud Pit C fence and SMs were in good condition. A pin on the gate lock hasp was missing, but it does not affect the integrity of the locking mechanism. No erosion or subsidence was observed on the cover. Mud Pits A, B, and D were in excellent condition, and no issues were identified with Area S or Area X (Figure 3-2). The overall condition of the site was good, and no issues were noted that affected the integrity of the cover and appurtenances.

\subsection{Subsidence Survey Results}

Surveys of the SMs for UC-1 and UC-4 were performed on August 12, 2008. A summary of the survey results is provided in the following sections.

\subsubsection{UC-1 Survey}

Twelve SMs were installed on the UC-1 CMP cover to provide elevation control and measure subsidence of the cover located above the CMP and relocation trench (NNSA/NV 2001). These SMs are shown in Figure 2-1. The baseline subsidence survey was completed on December 4, 2000, and is used as the reference to calculate subsidence for each subsequent survey. Beginning in 2007, annual subsidence monitoring replaced the biannual subsidence monitorings that had taken place since 2002. The UC-1 baseline survey locations and elevations are provided in Table 3-1 and presented in graphical form in Figure 3-3. 


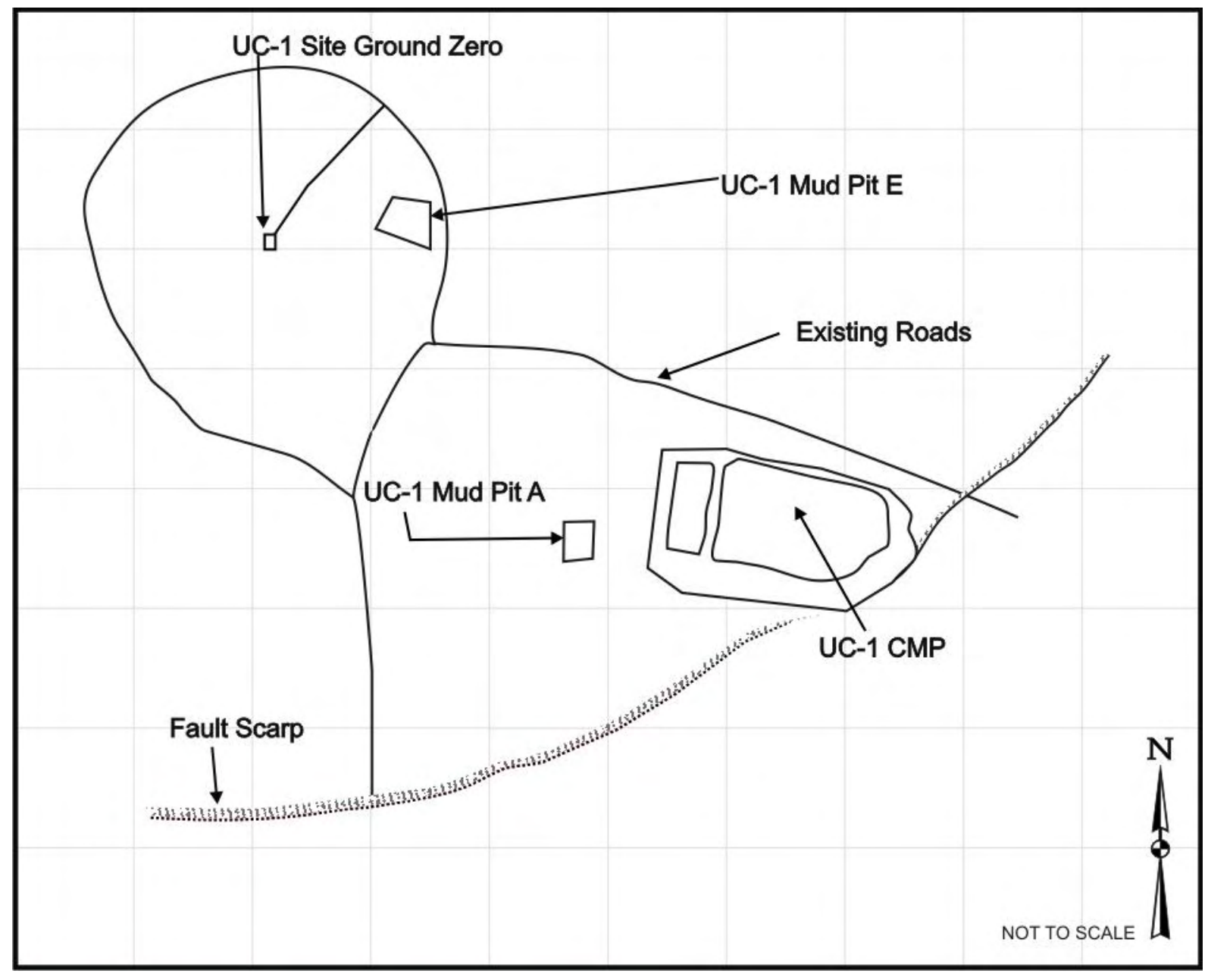

Figure 3-1. Location of UC-1 Mud Pits A and E 


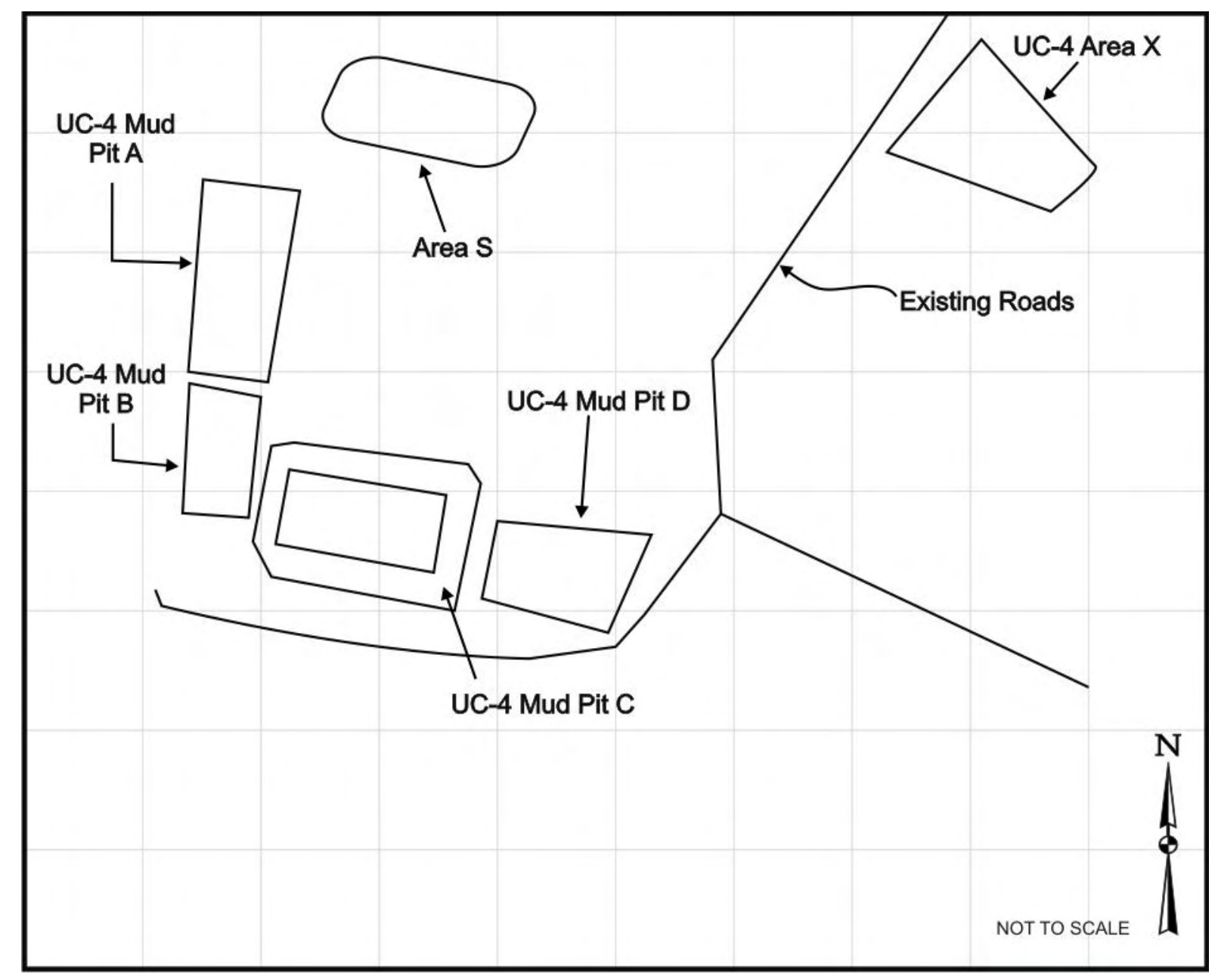

Figure 3-2. Location of UC-4 Mud Pits A, B, D, S, and X 


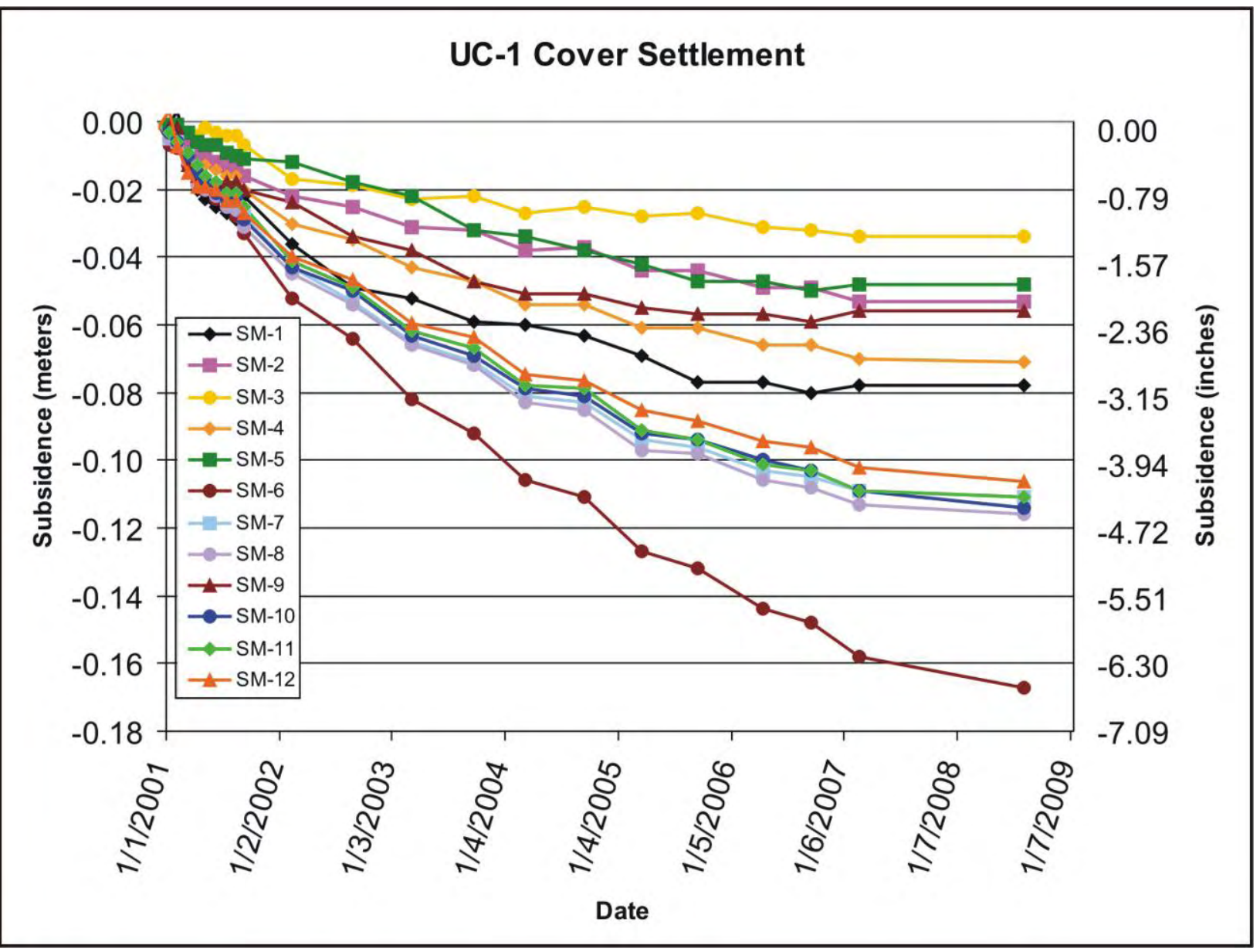

Figure 3-3. UC-1 Cover Settlement

The degree of settlement in both the relocation trench and the CMP is within the predicted range and shows no unusual subsidence. The data collected over the CMP section of the cover indicates that the largest subsidence is located along the centerline of the CMP, including SM-6, SM-7, and SM-8 and along the southern portion of the cap, SM-10, SM-11, and SM-12. This was expected because of the thicker layer of underlying mud in this area. The northern monuments SM-2, SM-3, and SM-4, along with the western-most monuments, SM-1, SM-5 and SM-9, show the least subsidence because of the thinner layer of underlying mud along this margin of the cover. The greatest degree of settlement continues to be on SM-6, which has subsided a total of $16.7 \mathrm{~cm}$ (6.6 in.) since the baseline survey in December 2000. 
Table 3-1. UC-1 Monument Elevations and Subsidence

\begin{tabular}{|c|c|c|c|c|c|c|c|c|c|c|c|c|}
\hline \multirow[b]{2}{*}{ Date } & \multicolumn{12}{|c|}{$\begin{array}{l}\text { Elevation at Top of Monument, } \\
\text { Subsidence }(\mathrm{m})\end{array}$} \\
\hline & $\begin{array}{c}\text { SM-1 } \\
\text { N 6,430,874.2869 } \\
\text { E 539,588.2339 }\end{array}$ & $\begin{array}{c}\text { SM-2 } \\
\text { N 6,430,863.3239 } \\
\text { E 539,644.8195 }\end{array}$ & $\begin{array}{c}\text { SM-3 } \\
\text { N 6,430,855.2553 } \\
\text { E 539,684.3327 }\end{array}$ & $\begin{array}{c}\text { SM-4 } \\
\text { N 6,430,849.7763 } \\
\text { E 539,715.7991 }\end{array}$ & $\begin{array}{c}\text { SM-5 } \\
\text { N 6,430,852.0243 } \\
\text { E 539,585.4651 }\end{array}$ & $\begin{array}{c}\text { SM-6 } \\
\text { N 6,430,841.7590 } \\
\text { E 539,641.4674 }\end{array}$ & $\begin{array}{c}\text { SM-7 } \\
\text { N 6,430,834.5289 } \\
\text { E 539,680.5243 }\end{array}$ & $\begin{array}{c}\text { SM-8 } \\
\text { N 6,430,828.6994 } \\
\text { E 539,712.4350 }\end{array}$ & \begin{tabular}{|c|} 
SM-9 \\
N 6,430,828.8720 \\
E 539,582.4750
\end{tabular} & $\begin{array}{c}\text { SM-10 } \\
\text { N 6,430,818.6353 } \\
\text { E 539.638.2030 }\end{array}$ & \begin{tabular}{|c|} 
SM-11 \\
N 6,430,812.8276 \\
E 539.676.0839
\end{tabular} & \begin{tabular}{|c|} 
SM-12 \\
N 6,430,806.7973 \\
E 539,708.9837
\end{tabular} \\
\hline \multirow{2}{*}{$\begin{array}{c}\text { 12/04/2000 } \\
\text { Baseline }\end{array}$} & 1836.604 & 1835.154 & 1834.995 & 1834.854 & 1836.541 & 1834.887 & 1834.709 & 1834.681 & \begin{tabular}{|c|}
1836.547 \\
\end{tabular} & 1834.943 & 1834.744 & 1834.635 \\
\hline & 0 & 0 & 0 & 0 & 0 & 0 & 0 & 0 & 0 & 0 & 0 & 0 \\
\hline \multirow{2}{*}{ 01/10/2001 } & 1836.603 & 1835.149 & 1834.991 & 1834.850 & 1836.540 & 1834.880 & 1834.704 & 1834.676 & 1836.545 & 1834.940 & 1834.741 & 1834.641 \\
\hline & -0.001 & -0.005 & -0.004 & -0.004 & -0.001 & -0.007 & -0.005 & -0.005 & -0.002 & -0.003 & -0.003 & 0.006 \\
\hline \multirow{2}{*}{ 2/06/2001 } & 1836.607 & 1835.150 & 1834.992 & 1834.849 & 1836.540 & 1834.879 & 1834.703 & 1834.674 & 1836.545 & 1834.937 & 1834.738 & 1834.630 \\
\hline & -0.003 & -0.004 & -0.003 & -0.005 & -0.001 & -0.008 & -0.006 & -0.007 & -0.002 & -0.006 & -0.006 & -0.005 \\
\hline \multirow{2}{*}{ 03/13/2001 } & 1836.595 & 1835.147 & 1834.992 & 1834.845 & 1836.538 & 1834.874 & 1834.699 & 1834.669 & 1836.534 & 1834.933 & 1834.735 & 1834.622 \\
\hline & -0.009 & -0.007 & -0.003 & -0.009 & -0.003 & -0.013 & -0.010 & -0.012 & -0.013 & -0.010 & -0.009 & -0.013 \\
\hline \multirow{2}{*}{ 04/11/2001 } & 1836.584 & 1835.144 & 1834.991 & 1834.841 & 1836.535 & 1834.869 & 1834.693 & 1834.662 & 1836.531 & 1834.928 & 1834.731 & 1834.618 \\
\hline & -0.020 & -0.010 & -0.004 & -0.013 & -0.006 & -0.018 & -0.016 & -0.019 & -0.016 & -0.015 & -0.013 & -0.017 \\
\hline \multirow{2}{*}{ 05/09/2001 } & 1836.581 & 1835.144 & 1834.993 & 1834.841 & 1836.534 & 1834.869 & 1834.691 & 1834.661 & 1836.529 & 1834.925 & 1834.728 & 1834.618 \\
\hline & -0.023 & -0.010 & -0.002 & -0.013 & -0.007 & -0.018 & -0.018 & -0.020 & -0.018 & -0.018 & -0.016 & -0.017 \\
\hline \multirow{2}{*}{ 6/12/2001 } & 1836.579 & 1835.142 & 1834.992 & 1834.840 & 1836.534 & 1834.864 & 1834.689 & 1834.659 & 1836.529 & 1834.922 & 1834.726 & 1834.617 \\
\hline & -0.025 & -0.012 & -0.003 & -0.014 & -0.007 & -0.023 & -0.020 & -0.022 & -0.018 & -0.021 & -0.018 & -0.018 \\
\hline \multirow{2}{*}{ 07/18/2001 } & 1836.577 & 1835.141 & 1834.991 & 1834.838 & 1836.532 & 1834.862 & 1834.686 & 1834.656 & 1836.529 & 1834.920 & 1834.723 & 1834.614 \\
\hline & -0.027 & -0.013 & -0.004 & -0.016 & -0.009 & -0.025 & -0.023 & -0.025 & -0.018 & -0.023 & -0.021 & -0.021 \\
\hline \multirow{2}{*}{$08 / 14 / 2001$} & 1836.575 & 1835.140 & 1834.991 & 1834.838 & 1836.531 & 1834.859 & 1834.685 & 1834.655 & 1836.529 & 1834.921 & 1834.723 & 1834.614 \\
\hline & -0.029 & -0.014 & -0.004 & -0.016 & -0.010 & -0.028 & -0.024 & -0.026 & -0.018 & -0.022 & -0.021 & -0.021 \\
\hline \multirow{2}{*}{ 09/12/2001 } & 1836.582 & 1835.138 & 1834.988 & 1834.834 & 1836.530 & 1834.854 & 1834.681 & 1834.650 & 1836.527 & 1834.914 & 1834.719 & 1834.610 \\
\hline & -0.022 & -0.016 & -0.007 & -0.020 & -0.011 & -0.033 & -0.028 & -0.031 & -0.020 & -0.029 & -0.025 & -0.025 \\
\hline \multirow{2}{*}{$02 / 13 / 2002$} & 1836.568 & 1835.132 & 1834.978 & 1834.824 & 1836.529 & 1834.835 & 1834.666 & 1834.636 & 1836.523 & 1834.900 & 1834.703 & 1834.597 \\
\hline & -0.036 & -0.022 & -0.017 & -0.030 & -0.012 & -0.052 & -0.043 & -0.045 & -0.024 & -0.043 & -0.041 & -0.038 \\
\hline \multirow{2}{*}{ 08/26/2002 } & 1836.555 & 1835.129 & 1834.976 & 1834.819 & 1836.523 & 1834.823 & 1834.656 & 1834.627 & 1836.513 & 1834.893 & 1834.695 & 1834.590 \\
\hline & -0.049 & -0.025 & -0.019 & -0.035 & -0.018 & -0.064 & -0.053 & -0.054 & -0.034 & -0.050 & -0.049 & -0.045 \\
\hline \multirow{2}{*}{ 03/06/2003 } & 1836.552 & 1835.123 & 1834.972 & 1834.811 & 1836.519 & 1834.805 & 1834.644 & 1834.615 & 1836.509 & 1834.880 & 1834.682 & 1834.577 \\
\hline & -0.052 & -0.031 & -0.023 & $\begin{array}{l}-0.043 \\
\end{array}$ & -0.022 & -0.082 & -0.065 & -0.066 & -0.038 & -0.063 & -0.062 & -0.058 \\
\hline \multirow{2}{*}{ 09/26/2003 } & 1836.545 & $\begin{array}{l}1835.122 \\
\end{array}$ & 1834.973 & 1834.807 & 1836.509 & 1834.795 & 1834.638 & $\begin{array}{l}1834.609 \\
\end{array}$ & 1836.500 & \begin{tabular}{|l|l|l|}
1834.874 \\
\end{tabular} & 1834.677 & 1834.573 \\
\hline & -0.059 & -0.032 & -0.022 & -0.047 & -0.032 & -0.092 & -0.071 & -0.072 & -0.047 & -0.069 & -0.067 & -0.062 \\
\hline \multirow{2}{*}{$03 / 10 / 2004$} & 1836.544 & 1835.116 & 1834.968 & 1834.800 & 1836.507 & 1834.781 & 1834.628 & 1834.598 & 1836.496 & 1834.864 & 1834.666 & 1834.562 \\
\hline & -0.060 & -0.038 & -0.027 & -0.054 & -0.034 & -0.106 & -0.081 & -0.083 & -0.051 & -0.079 & -0.078 & -0.073 \\
\hline \multirow{2}{*}{ 09/15/2004 } & 1836.541 & 1835.117 & 1834.970 & 1834.800 & 1836.503 & 1834.776 & 1834.626 & $\begin{array}{l}1834.596 \\
\end{array}$ & 1836.496 & 1834.862 & 1834.665 & 1834.560 \\
\hline & -0.063 & -0.037 & -0.025 & -0.054 & -0.038 & -0.111 & -0.083 & -0.085 & -0.051 & -0.081 & -0.079 & -0.075 \\
\hline \multirow{2}{*}{ 03/22/2005 } & 1836.535 & 1835.110 & 1834.967 & $\begin{array}{l}1834.793 \\
\end{array}$ & 1836.499 & 1834.760 & 1834.615 & $\begin{array}{l}1834.584 \\
\end{array}$ & 1836.492 & 1834.851 & 1834.653 & 1834.551 \\
\hline & -0.069 & -0.044 & -0.028 & -0.061 & -0.042 & -0.127 & -0.094 & -0.097 & -0.055 & -0.092 & -0.091 & -0.084 \\
\hline \multirow{2}{*}{ 09/21/2005 } & 1836.527 & 1835.110 & 1834.968 & 1834.793 & 1836.494 & 1834.755 & 1834.613 & 1834.583 & 1836.490 & 1834.849 & 1834.650 & 1834.548 \\
\hline & -0.077 & -0.044 & -0.027 & -0.061 & -0.047 & -0.132 & -0.096 & -0.098 & -0.057 & -0.094 & -0.094 & -0.087 \\
\hline $04 / 19 / 2006$ & 1836.527 & 1835.105 & 1834.964 & 1834.788 & 1836.494 & 1834.743 & 1834.606 & 1834.575 & 1836.490 & 1834.843 & 1834.643 & 1834.542 \\
\hline 04/19/2006 & -0.077 & -0.049 & -0.031 & -0.066 & -0.047 & -0.144 & -0.103 & -0.106 & -0.057 & -0.100 & -0.101 & $\begin{array}{l}-0.093 \\
\end{array}$ \\
\hline $09 / 19 / 2006$ & 1836.524 & 1835.105 & 1834.963 & 1834.788 & 1836.491 & 1834.739 & 1834.604 & 1834.573 & $\begin{array}{l}1836.488 \\
\end{array}$ & 1834.840 & 1834.641 & 1834.54 \\
\hline 09/19/2006 & -0.08 & -0.049 & -0.032 & -0.066 & -0.05 & -0.148 & -0.105 & -0.108 & -0.059 & -0.103 & -0.103 & -0.095 \\
\hline 0212210007 & 1836.526 & 1835.101 & 1834.961 & 1834.784 & 1836.493 & 1834.729 & 1834.600 & 1834.568 & 1836.491 & 1834.834 & 1834.635 & 1834.534 \\
\hline $02 / 22 / 2007$ & -0.078 & -0.053 & -0.034 & -0.070 & -0.048 & -0.158 & -0.109 & -0.113 & -0.056 & -0.109 & -0.109 & -0.101 \\
\hline $08 / 12 / 2008$ & 1836.526 & 1835.101 & 1834.961 & 1834.783 & 1836.493 & 1834.720 & 1834.598 & 1834.565 & 1836.491 & 1834.829 & 1834.633 & 1834.530 \\
\hline 08/12/2008 & -0.078 & -0.053 & -0.034 & -0.071 & -0.048 & -0.167 & -0.111 & -0.116 & -0.056 & -0.114 & -0.111 & -0.105 \\
\hline
\end{tabular}

aVertical datum: National Geodetic Vertical Datum of 1929 in meters
bHorizontal datum: U.S. State Plane 1983; vertical datum: National Geodetic Vertical Datum of 1929

$N=$ northing
$E=$ easting 
This page intentionally left blank 


\subsubsection{UC-4 Survey}

Two permanent SMs (west and east monuments) were installed in the cover to provide elevation control for measuring the subsidence of the cover. These SMs are shown in Figure 3-4. The baseline subsidence survey was completed on October 12,1999, and is used as the reference survey to calculate subsidence. The UC-4 baseline survey locations and elevations are provided in Table 3-2 and are presented in graphical form in Figure 3-5. Settling of the west monument is still slightly greater than the predicted settling of $5 \mathrm{~cm}(2 \mathrm{in}$.); the total subsidence is $6.4 \mathrm{~cm}$ (2.5 in.) since the baseline survey in October 1999. The east monument has subsided a total of $2.7 \mathrm{~cm}$ (1.1 in.) since the baseline survey. The largest changes occurred within the first year.

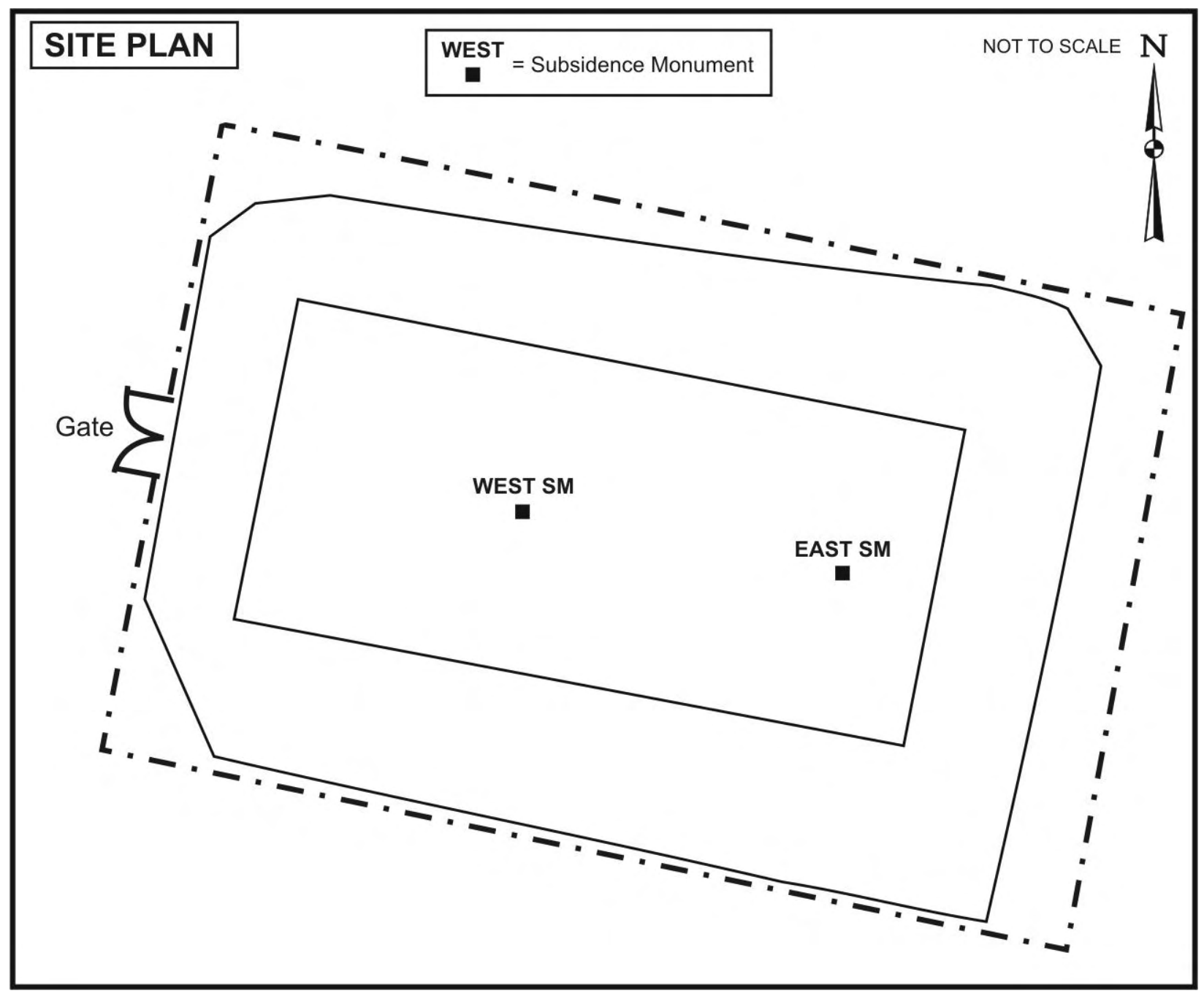

Figure 3-4. UC-4 West and East Monuments 
Table 3-2. UC-4 Monument Elevations and Subsidence

\begin{tabular}{|c|c|c|}
\hline \multirow[b]{2}{*}{ Date } & \multicolumn{2}{|c|}{$\frac{\text { Elevation at Top of Monument }^{\mathrm{a}, \mathrm{b}}}{\text { Subsidence }(\mathrm{m})}$} \\
\hline & $\begin{array}{c}\text { West Monument } \\
\text { N 6,435,982.965 } \\
\text { E 538,966.436 }\end{array}$ & $\begin{array}{c}\text { East Monument } \\
\text { N 6,435,978.404 } \\
\text { E 538,992.231 }\end{array}$ \\
\hline \multirow{2}{*}{$\begin{array}{l}\text { 10/12/1999 } \\
\text { Baseline }\end{array}$} & 1999.269 & 1999.062 \\
\hline & 0.000 & 0.000 \\
\hline \multirow{2}{*}{ 11/29/1999 } & 1999.260 & 1999.056 \\
\hline & -0.009 & -0.006 \\
\hline \multirow{2}{*}{$01 / 14 / 2000$} & 1999.254 & 1999.052 \\
\hline & -0.015 & -0.010 \\
\hline \multirow{2}{*}{$02 / 28 / 2000$} & 1999.251 & 1999.053 \\
\hline & -0.018 & -0.009 \\
\hline \multirow{2}{*}{$03 / 28 / 2000$} & 1999.247 & 1999.052 \\
\hline & -0.022 & -0.010 \\
\hline \multirow{2}{*}{$04 / 27 / 2000$} & 1999.242 & 1999.05 \\
\hline & -0.027 & -0.012 \\
\hline \multirow{2}{*}{ 06/01/2000 } & 1999.241 & 1999.05 \\
\hline & -0.028 & -0.012 \\
\hline \multirow{2}{*}{$02 / 13 / 2002$} & 1999.216 & 1999.037 \\
\hline & -0.053 & -0.025 \\
\hline \multirow{2}{*}{ 08/27/2002 } & 1999.214 & 1999.039 \\
\hline & -0.055 & -0.023 \\
\hline \multirow{2}{*}{ 03/06/2003 } & 1999.21 & 1999.036 \\
\hline & -0.059 & -0.026 \\
\hline \multirow{2}{*}{ 09/26/2003 } & 1999.207 & 1999.035 \\
\hline & -0.062 & -0.027 \\
\hline \multirow{2}{*}{ 03/10/2004 } & 1999.208 & 1999.036 \\
\hline & -0.061 & -0.026 \\
\hline \multirow{2}{*}{$09 / 14 / 2004$} & 1999.209 & 1999.041 \\
\hline & -0.060 & -0.021 \\
\hline \multirow{2}{*}{$03 / 22 / 2005$} & 1999.206 & 1999.037 \\
\hline & -0.063 & -0.025 \\
\hline \multirow{2}{*}{$09 / 21 / 2005$} & 1999.206 & 1999.036 \\
\hline & -0.063 & -0.026 \\
\hline \multirow{2}{*}{ 04/18/2006 } & 1999.203 & 1999.033 \\
\hline & -0.066 & -0.029 \\
\hline \multirow{2}{*}{$09 / 19 / 2006$} & 1999.203 & 1999.034 \\
\hline & -0.066 & -0.029 \\
\hline \multirow{2}{*}{$02 / 22 / 2007$} & 1999.203 & 1999.031 \\
\hline & -0.066 & -0.031 \\
\hline \multirow{2}{*}{$08 / 12 / 2008$} & 1999.205 & 1999.035 \\
\hline & -0.064 & -0.027 \\
\hline
\end{tabular}

${ }^{\mathrm{a}}$ Vertical datum: National Geodetic Vertical Datum of 1929 in meters

${ }^{\mathrm{b}}$ Horizontal datum: U.S. State Plane 1983; Vertical datum: North American Vertical Datum of 1929

$\mathrm{N}=$ northing

$E=$ easting 


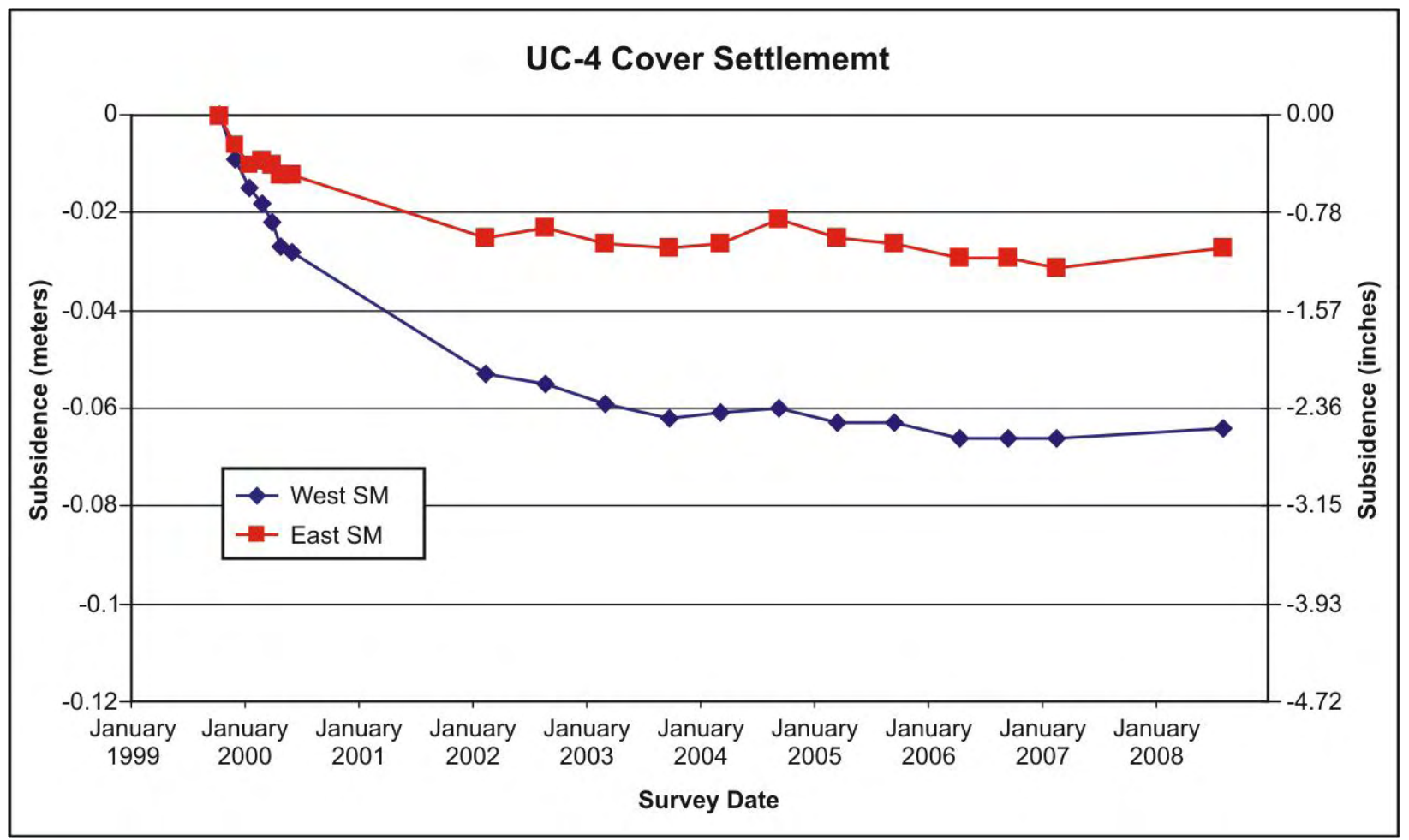

Figure 3-5. UC-4 Cover Settlement

\subsection{Vegetation Survey Results}

A vegetation survey was not performed in 2008 . The next vegetation survey will be conducted in 2009.

\subsection{Precipitation and Soil Moisture Monitoring Results}

Precipitation data are collected at the UC-1 CMP cover by a Campbell Scientific TE525 tipping bucket rain gauge. A CS705 precipitation adapter is used for snowfall measurements. The rain gauge data are collected and stored by the data logger and sent to an onsite telemetry station where the data are sent and saved to SOARS. The rain gauge was evaluated and repaired during a general site maintenance visit conducted in early October 2008.

The precipitation record from the UC-1 CMP rain gauge is presented in Figure 3-6. Precipitation measured from July 1, 2007 to June 30, 2008 was below average; totaling 1.52 millimeters (0.06 in.).

\subsubsection{UC-1 Soil Moisture Results}

Graphs of the TDR-derived soil moisture content for July 1, 2007 through June 30, 2008 are presented in Figure 3-7 through Figure 3-10. 


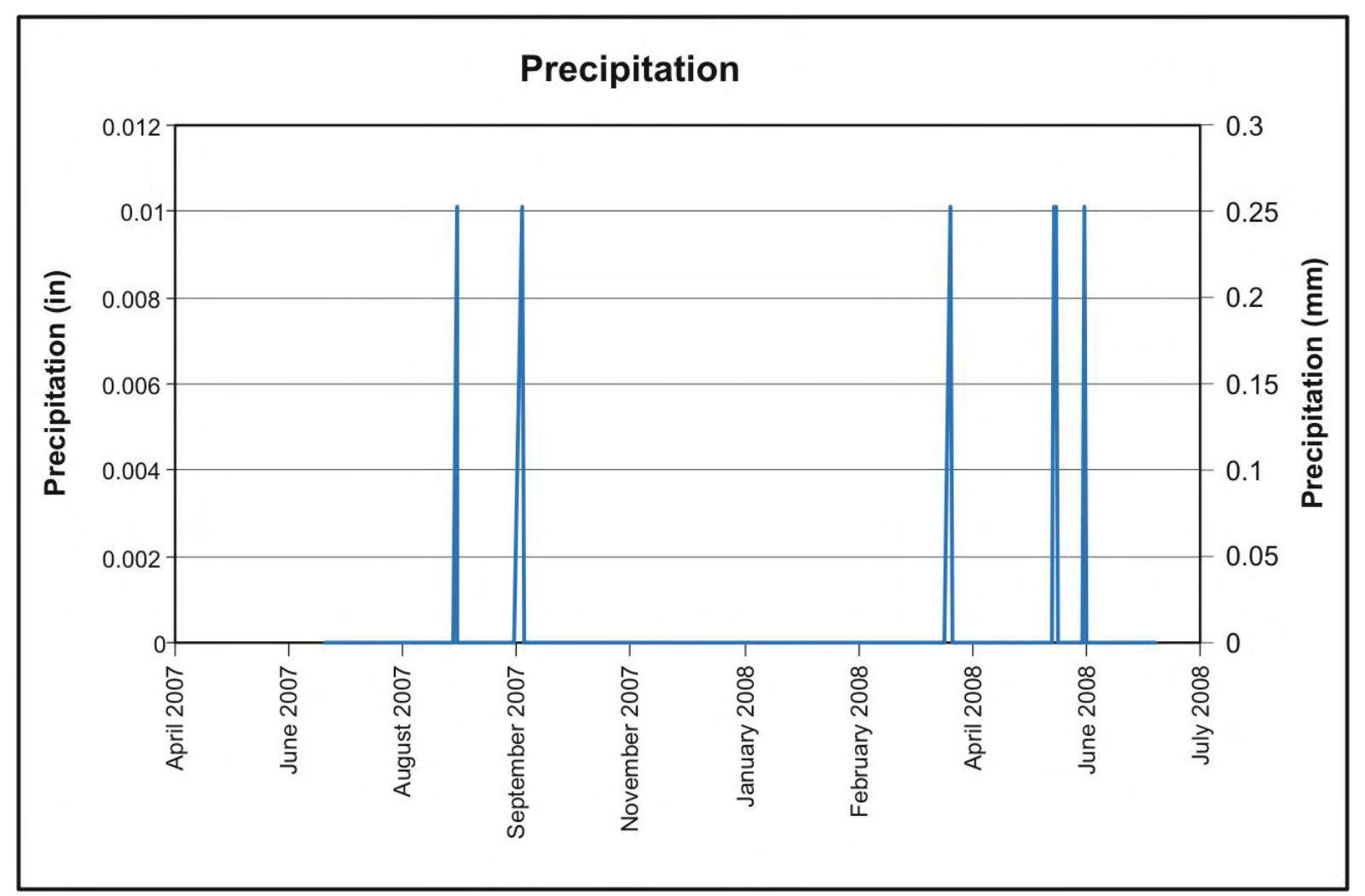

Figure 3-6. July 1, 2007 through June 1, 2008 Precipitation Data

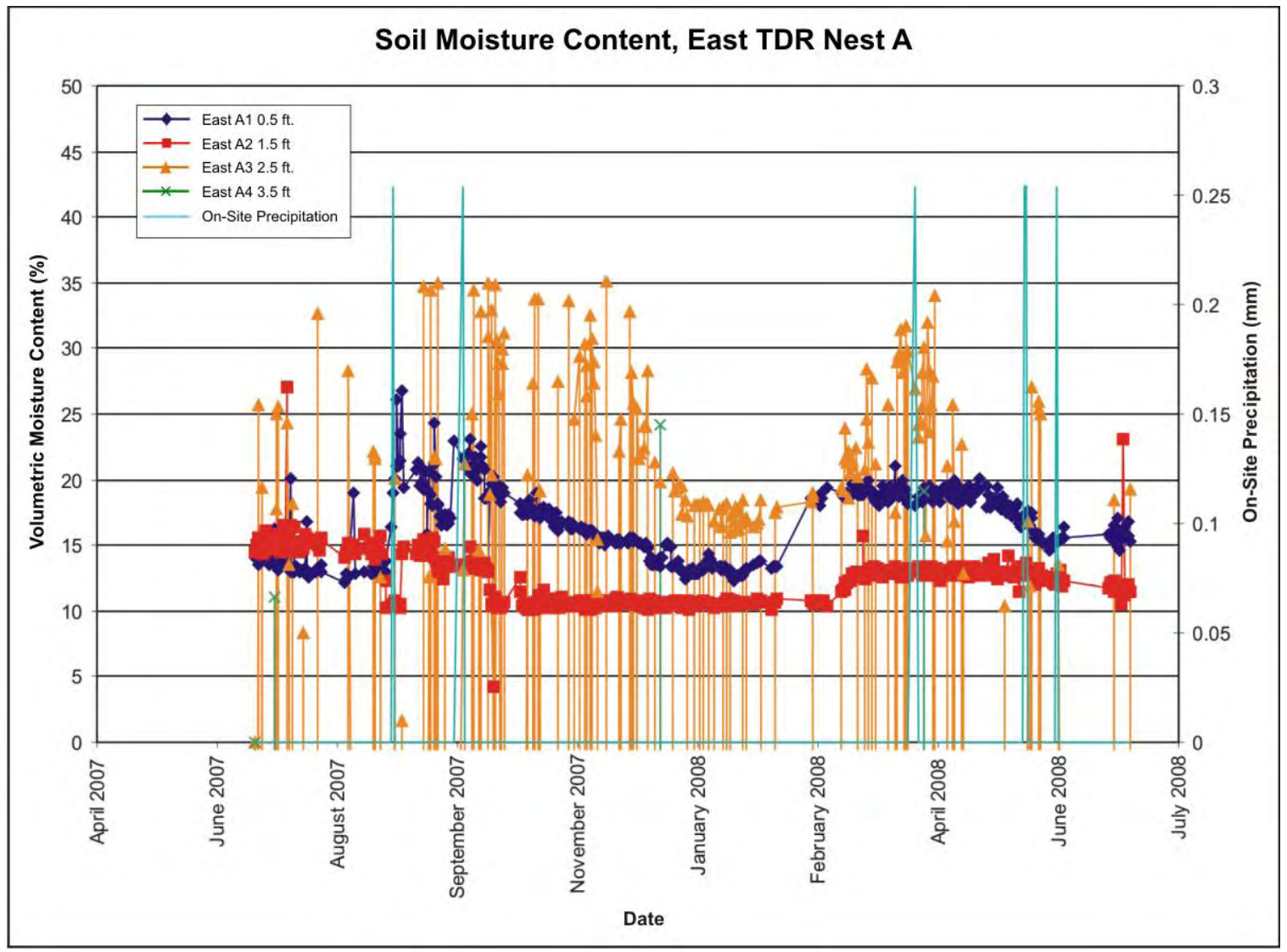

Figure 3-7. UC-1 Soil Moisture Content, East TDR Nest A 


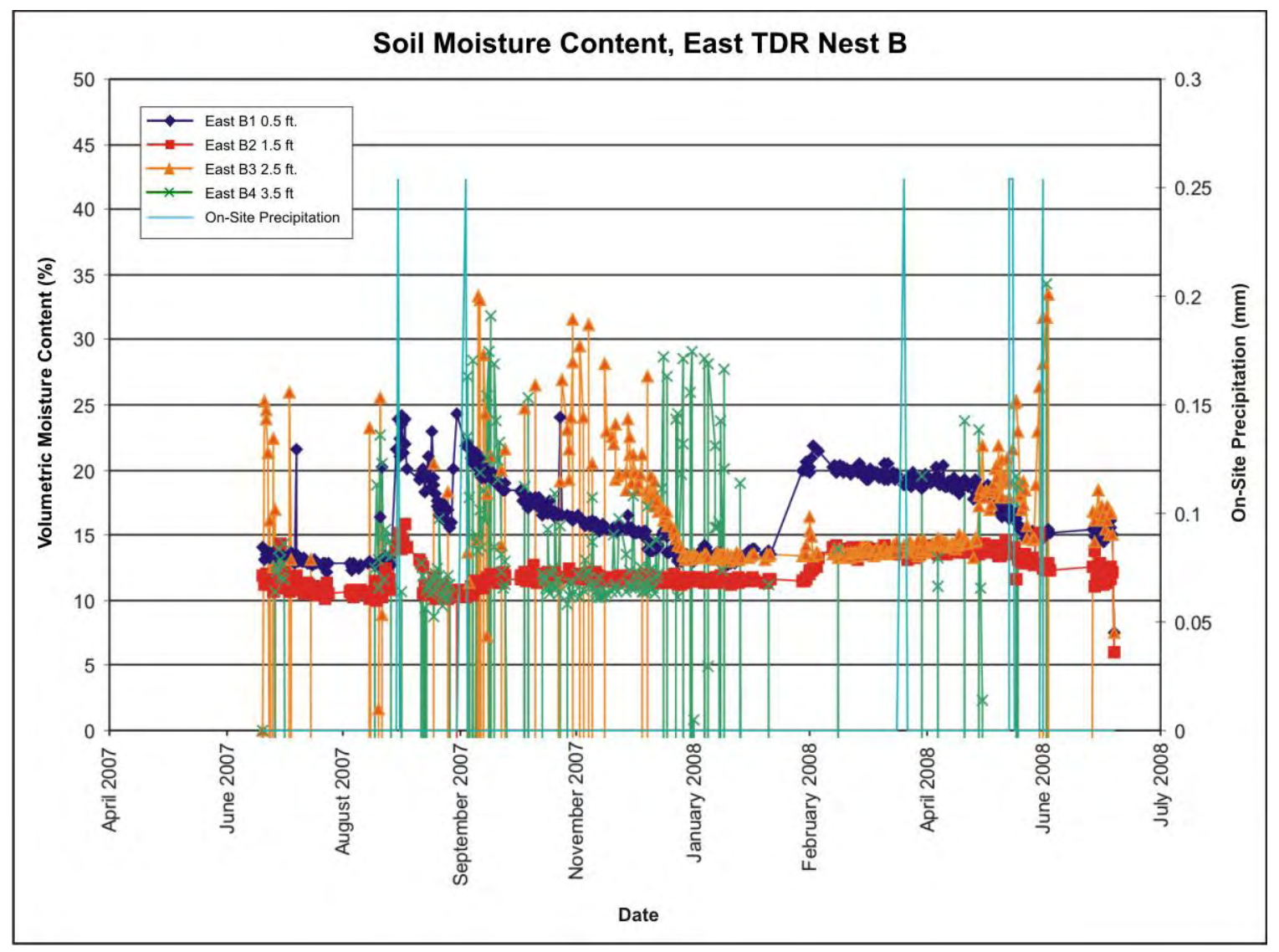

Figure 3-8. UC-1 Soil Moisture Content, East TDR Nest B 


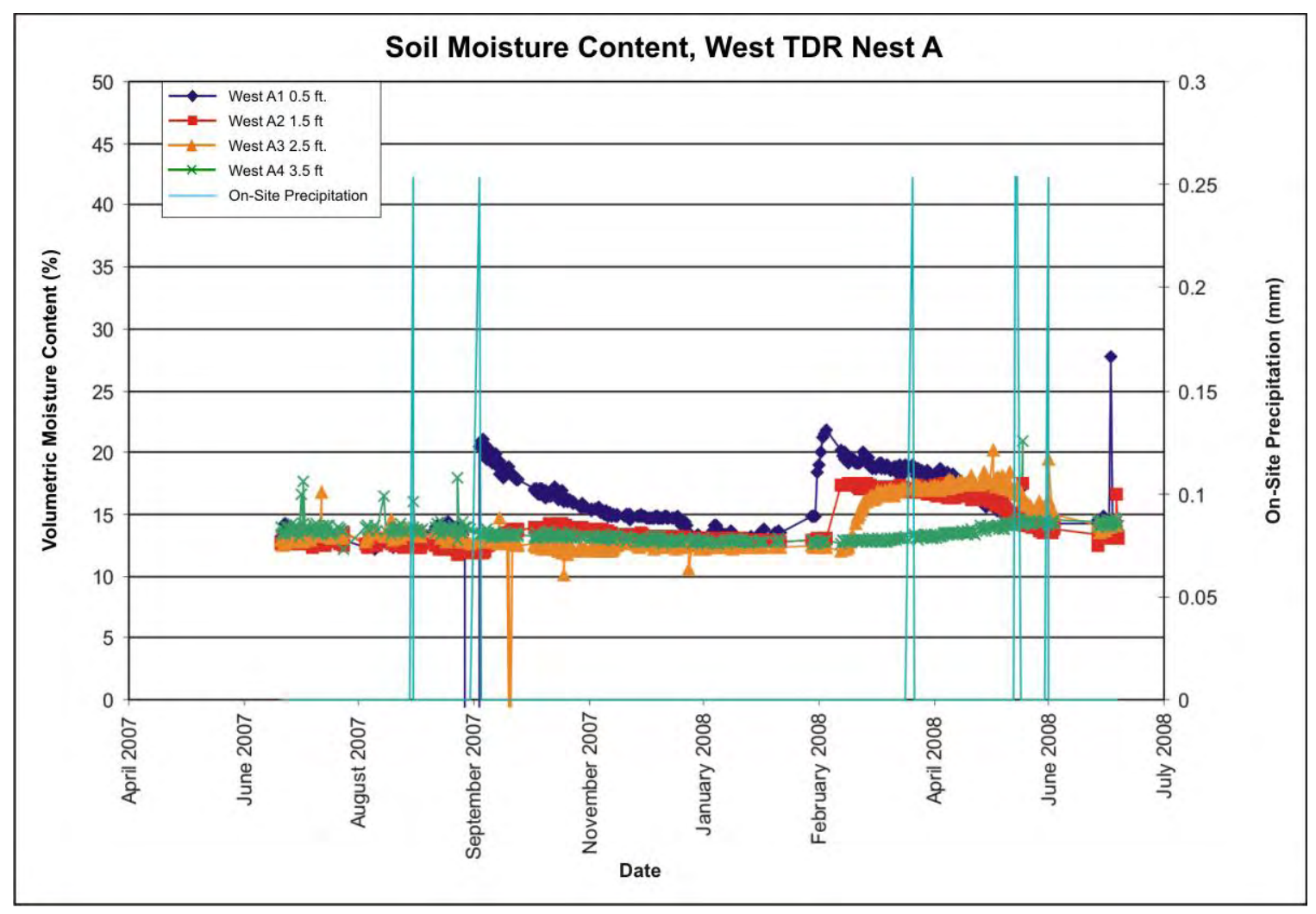

Figure 3-9. UC-1 Soil Moisture Content, West TDR Nest A

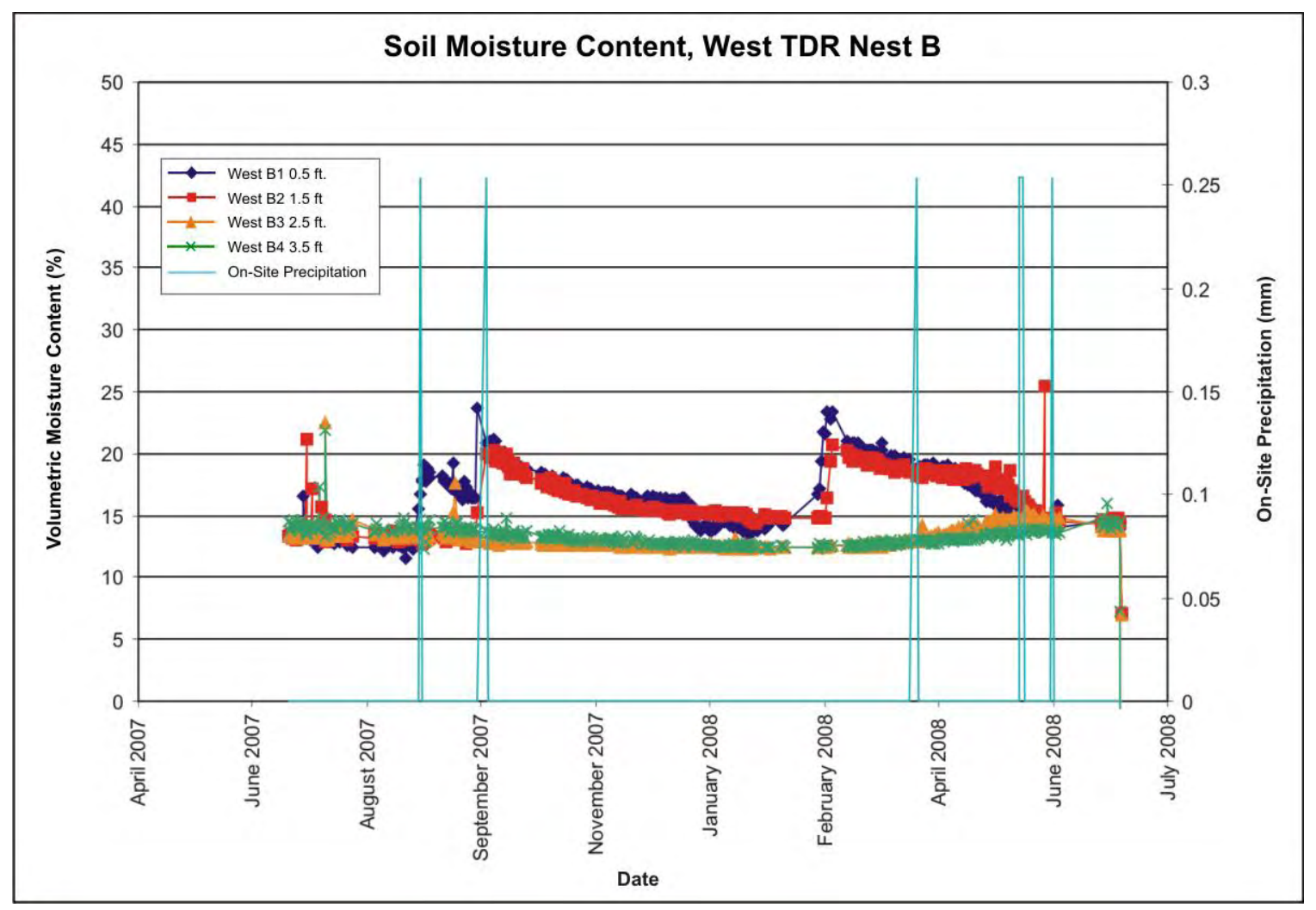

Figure 3-10. UC-1 Soil Moisture Content, West TDR Nest B 


\section{UC-1 East TDR Nest}

TDR data obtained for the east nests, measured at depths of 0.76 meters and 1.07 meters $(2.5 \mathrm{ft}$ and $3.5 \mathrm{ft}$, respectively), were entirely corrupted from an unknown cause. Previously, the lengthy cable created a problem in measuring the reflected signal from the TDR probes (NNSA/NV 2007). Inappropriate signal responses from the two lower stations in the east TDR nest make interpretation of the data difficult. Only the upper two depths are presented on the respective graphs, and from the profiles, it is difficult to assess performance of the cover. From these data it appears that the volumetric moisture content fluctuates by less than one percent in the upper $1.5 \mathrm{ft}$ of the cap.

\section{UC-1 West TDR Nest}

Moisture content measurements indicate steady-state conditions throughout the year with volumetric moisture content varying by less than one percent in the upper $2.5 \mathrm{ft}$ of the cap.

Overall, both nests present similar profiles and indicate that the cover is performing as designed, with evapotranspiration effectively removing water from the cover. The moisture content at the two deeper profiles of the west TDR nest appears to be approaching steady-state conditions. The moisture sensors in the two deeper profiles of the east TDR nest are not functioning. 
This page intentionally left blank

Page 3-14 


\subsection{Summary, Conclusions, and Recommendations}

\subsection{Summary}

The 2008 annual inspection of UC-1 CMP indicated continued integrity of the cover unit. Three new cracks or fractures were observed on the UC-1 CMP cover during the annual 2008 inspection. These cracks were repaired with an application of bentonite fill at the time of the inspection. No issues were identified with the fence or gate.

No vegetation survey was conducted in 2008 . The next vegetation survey will be performed in 2009 .

Precipitation from July 1, 2007 to June 30, 2008 was below average; the rainfall total was 1.52 millimeters (0.06 inches). According to the Western Regional Climate Center of Reno, Nevada, CNTA's location experienced severe drought conditions during this period. Soil moisture content data shows that the UC-1 cover is performing as designed and evapotranspiration effectively removing water from the cover.

The UC-1 settling trend that has been occurring since December 2000 continued to show a slight decrease in elevation during the current monitoring period, and most survey monuments showed only small changes from the 2007 to 2008 survey. The degree of settling in both the relocation trench and the CMP is within the predicted range and shows no unusual subsidence.

The inspection of UC-3 indicated that the sites are in excellent condition. All monuments and use-restriction signs are in good condition. No issues were identified, and no maintenance or repair activities are recommended at this time.

The inspection of UC-4 indicated that the sites are in excellent condition. All monuments and use-restriction signs are in good condition. No concerns were identified with the monuments or gate.

In the annual survey, measurements at the UC-4 east monument indicated a slight decrease in elevation. Subsidence at the west monument is still slightly greater than the predicted settling; the total subsidence was $6.6 \mathrm{~cm}$ (2.6 in.) since the baseline survey in October 1999. Settling of the monuments appears to have stabilized.

\subsection{Conclusions}

- $\quad$ No significant concerns were noted for the UC-1 CMP and UC-4 Mud Pit C covers during the annual inspection, and no further maintenance or repairs are recommended at this time.

- $\quad$ No significant concerns were noted on the subsidence surveys for UC-1 and UC-4.

- $\quad$ Soil moisture monitoring data indicates that the cover is performing as designed, and that evapotranspiration appears to be effectively removing water from the cover.

- $\quad$ The soil moisture monitoring compliance criteria cannot be established at this time because of below average rainfall during the past year. 


\subsection{Recommendations}

- Continue site inspections annually as scheduled to observe the condition of the covers, fence, vegetation, signs, and monuments.

- $\quad$ Continue annual subsidence surveys on UC-1 and UC-4.

- $\quad$ Conduct a vegetation survey in 2009 in order to comply with the agreement to perform the vegetation survey biannually.

- $\quad$ Continue soil moisture data collection from the west TDR nest and, when possible, from the east TDR nest.

- Meet with NDEP to discuss the closure plan with respect to historical site data collected, present site conditions, and future path forward. 


\subsection{References}

Barnes, W., 1968. Report of Exploration Progress, Central Nevada, Period August 1, 1967 December 31, 1967, U.S. Geological Survey Technical Letter, Central Nevada 3-2.

DOE/NV (U.S. Department of Energy, Nevada Operations Office), 2000. Corrective Action Plan for Corrective Action Unit 417: Central Nevada Test Area Surface, Nevada, DOE/NV-588, Las Vegas, Nevada.

FFACO (Federal Facility Agreement and Consent Order), 1996 (as amended). Agreed to by the State of Nevada, the U.S. Department of Energy, and the U.S. Department of Defense.

Healey, D. L., 1968. Gravity Survey of Northern Hot Creek Valley, Nye County, Nevada, U.S. Geological Survey Technical Letter, Central Nevada-18.

NNSA/NV (U.S. Department of Energy, National Nuclear Security Administration Nevada Operations Office), 2001. Closure Report for Corrective Action Unit 417: Central Nevada Test Area Surface, Nevada, DOE/NV-743, Rev. 1, Las Vegas, Nevada.

NNSA/NV (U.S. Department of Energy, National Nuclear Security Administration Nevada Operations Office), 2007. Post-Closure Inspection and Monitoring Report for Corrective Action Unit 417: Central Nevada Test Area-Surface Hot Creek Valley, Nevada, DOE/NV/25946-168, Las Vegas, Nevada.

Topp, G.C., Davis, J.L., and Annan, A.P. (1980). Electromagnetic determination of soil water content: measurements in coaxial transmission lines. Water Resources Research, vol. 16, pp. 574-582. 
This page intentionally left blank 
Appendix A

Inspection Checklists and Photographs 
This page intentionally left blank 


\begin{tabular}{|c|c|c|c|}
\hline \multicolumn{4}{|c|}{ CAU 417: CNTA UC-1 CENTRAL MUD PIT COVER, POST-CLOSURE INSPECTION CHECKLIST } \\
\hline Date of Last Inspection: May 15,2007 & \multicolumn{3}{|c|}{ Reason for Last Inspection: AnMual inspectron } \\
\hline Responsible Agency: DOE $\angle M$ & \multicolumn{3}{|c|}{ Project Manager: RICK HUTTON } \\
\hline \multirow{2}{*}{\multicolumn{4}{|c|}{ Inspection Date: May 13,2008}} \\
\hline & & & \\
\hline \multicolumn{4}{|c|}{ Assistant inspector (name, title, organization): Ahdria Dutcher, 4 s S Specialust, S.M. STOUER } \\
\hline \multicolumn{4}{|c|}{$\begin{array}{l}\text { A. GENERAL INSTRUCTIONS } \\
\text { 1. All checklist items must be completed and detailed comments made to document the results of the site inspection. The completed } \\
\text { checklist is part of the field record of the inspection. Additional pages should be used as necessary to ensure that a complete } \\
\text { record is made. Attach the additional pages and number all pages upon completion of the inspection. } \\
\text { 3. Any checklist line item marked by an inspector in a SHADED BOX, must be fully explained or an appropriate reference to previous } \\
\text { reports provided. The purpose of this requirement is to provide a written explanation of inspector observations and the inspector's } \\
\text { rationale for conclusions and recommendations. Explanations are to be placed on additional attachments and cross-referenced } \\
\text { appropriately. Explanations, in addition to narrative, will take the form of sketches, measurements, annotated site maps. } \\
\text { 4. The site inspection is a walking inspection of the entire site including the perimeter and sufficient transects to be able to inspect the } \\
\text { entire surface and all features specifically described in this checklist. } \\
\text { 5. A standard set of color } 35 \text { mm photographs (or equivalent) is required. In addition, all anomalous features or new features (such } \\
\text { as changes in adjacent area land use) are to be photographed. A photo log entry will be made for each photograph taken. } \\
\text { 6. This unit will be inspected blannually with formal reporting to the Nevada Division of Environmental Protection to be done annually. } \\
\text { The annual report will include an executive summary, this inspection checklist with field notes and photo log attached, and } \\
\text { recommendations and conclusions. }\end{array}$} \\
\hline B. PREPARATION (To be completed prior to site visit) & YES & NO & EXPLANATION \\
\hline \multicolumn{4}{|l|}{ 1. Site as-built plans and site base map reviewed. } \\
\hline \multirow{3}{*}{$\begin{array}{l}\text { 2. Previous inspection reports reviewed. } \\
\text { a. Were anomalies or trends detected on previous inspections? } \\
\text { b. Was maintenance performed? }\end{array}$} & & & \\
\hline & & & \\
\hline & & & Sigus replaced and cracks fille \\
\hline \multirow{3}{*}{$\begin{array}{l}\text { 3. Site maintenance and repair records reviewed. } \\
\text { a. Has site repair resulted in a change from as-built conditions? } \\
\text { b. Are revised as-builts available that reflect repair changes? }\end{array}$} & $\checkmark$ & & \\
\hline & & & \\
\hline & & & $N / 4$ \\
\hline C. SITE INSPECTION (To be completed during inspection) & YES & NO & EXPLANATION \\
\hline \multicolumn{4}{|l|}{ 1. Adjacent off-site features within watershed areas. } \\
\hline a. Have there been any changes in use of adjacent area? & & & \\
\hline b. Are there any new roads or tralls? & & & \\
\hline c. Has there been a change in the position of nearby washes? & & & \\
\hline $\begin{array}{l}\text { d. Has there been lateral excursion or erosion/deposition of } \\
\text { nearby washes? }\end{array}$ & & & \\
\hline e. Are there new drainage channels? & & & \\
\hline f. Change in surrounding vegetation? & & & \\
\hline & & & \\
\hline $\begin{array}{l}\text { a. Displacement of fences, site markers, boundary markers, or } \\
\text { monuments? }\end{array}$ & & & \\
\hline $\begin{array}{l}\text { b. Have any signs been damaged or removed? } \\
\text { (Number of signs replaced: }\end{array}$ & & & \\
\hline c. Were gates locked? & & & \\
\hline
\end{tabular}


CAU 417: CNTA UC-1 CENTRAL MUD PIT COVER, POST-CLOSURE MONITORING CHECKLIST

3. Waste Unit cover.

a. Is there evidence of settling?

b. Is there cracking?

c. Is there evidence of erosion around the cap (wind or water)?

d. Is there evidence of animal burrowing?

e. Have the site markers been disturbed by man or natural processes?

f. Do natural processes threaten to integrity of any cover or site marker?

g. Other?

\begin{tabular}{|c|c|c|}
\hline YES & NO & EXPLANATION \\
\hline$V$ & & See subsidence Mon itormg data \\
\hline$v$ & & several cracks nistorically \\
\hline & & Erosional $r i l l m$ east stope \\
\hline & $V$ & \\
\hline & & \\
\hline & $\checkmark$ & \\
\hline & & Not applicable \\
\hline
\end{tabular}

4. Vegetative cover.

a. Is perimeter fence or mesh fencing damaged?

b. Is there evidence of horses or rabbits on site?

c. Is organic mulch and/or plants adequate to prevent erosion?

d. Are weedy annual plants present? If yes, are they a problem?

e. Are seeded plant species found on site?

f. Is there evidence of plant mortality?

\begin{tabular}{|l|l|l|}
\hline & $\checkmark$ & \\
\hline & $\checkmark$ & \\
\hline$\nearrow$ & & \\
\hline & $\checkmark$ & \\
\hline$\nearrow$ & & \\
\hline$\checkmark$ & & Drought coudition exist \\
\hline
\end{tabular}

5. Photo Documentation

a. Has a photo log been prepared?

c. Number of photos exposed ( 9 )

\section{FIELD CONCLUSIONS}

1. Is there an imminent hazard to the integrity of the unit? (Immediate report required)

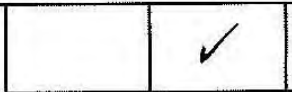

Person/Agency to whom report made:

2. Are more frequent inspections required?

3. Are existing maintenance/repair actions satisfactory?

4. Is other maintenance/repair necessary?

5. Is current status/condition of vegetative cover satisfactory?

Drought couditious exast

6. Rationale for field conclusions: Overall integrity of the cover in good. Three cracks were filled with bentouite chuse. Jhe erosioual rill on the east side of the coven will be mouitored to defermine of refion in needed at the next annual inspection.

\section{E. CERTIFICATION}

I have conducted an inspection of the UC-1 Cental Mud Pit Cover, CAU 417, at the Central Nevada Test Area in accordance with the PostClosure Monitoring Plan (see Closure Report) as recorded on this checklist, attached sheets, field notes, photo logs, and photographs.

Chief Inspector's Signature: Paul $9.8 \mathrm{Th} \quad$ Printed Name: PAKL S. DARR

Title:

Project specialist

Date:

$\operatorname{May} 13,2008$ 


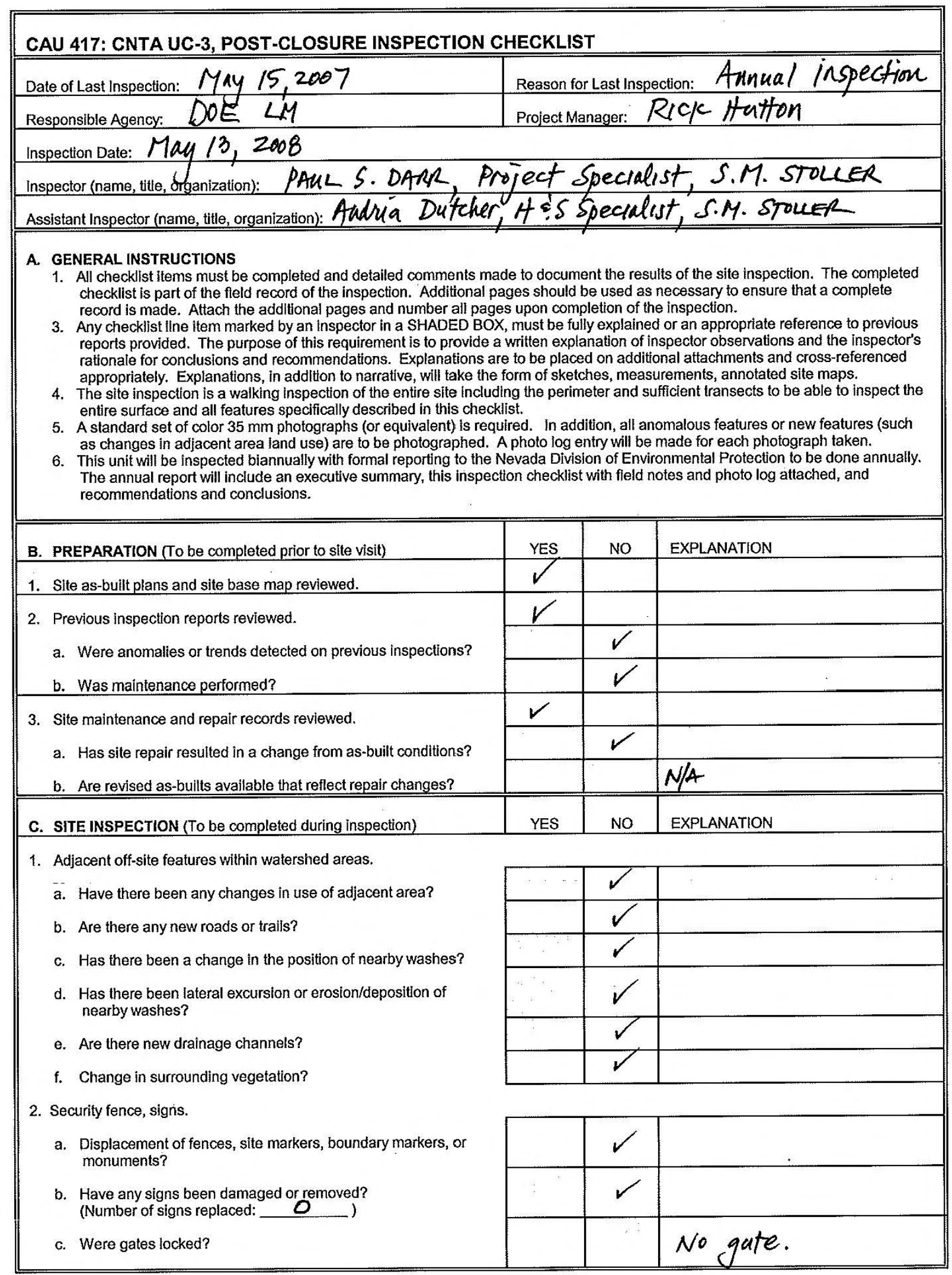




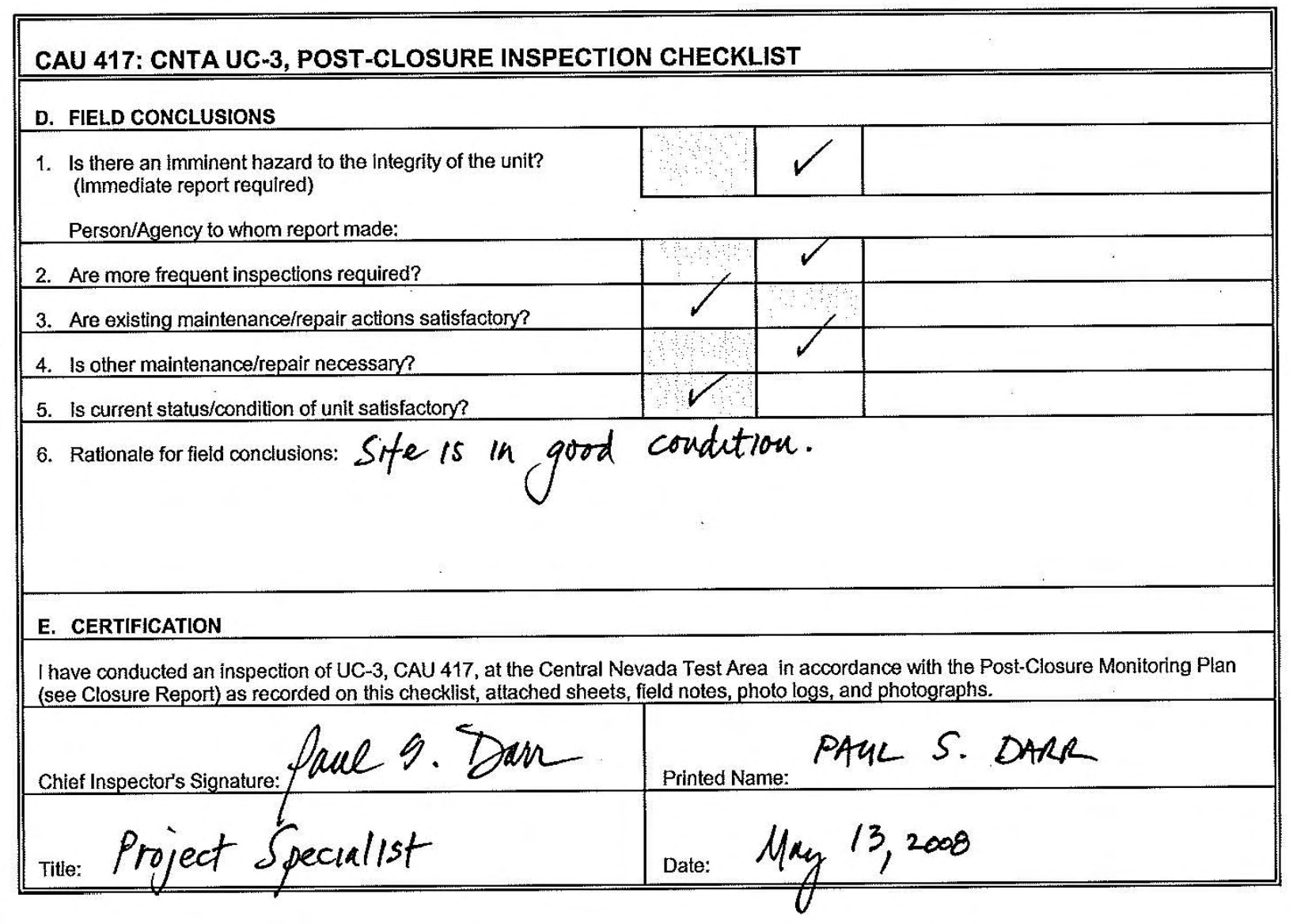




\begin{tabular}{|c|c|c|c|}
\hline \multicolumn{4}{|c|}{ CAU 417: CNTA UC-4 MUD PIT C COVER, POST-CLOSURE INSPECTION CHECKLIST } \\
\hline Date of Last Inspection: May 15,2007 & \multicolumn{3}{|c|}{ Reason for Last inspection: Annual inspection } \\
\hline Responsible Agency: $D O E L M$ & \multicolumn{3}{|c|}{ Project Manager: $R$ ck Hatton } \\
\hline \multicolumn{4}{|l|}{ Inspection Date: $\mathrm{Mag} / 3,2008$} \\
\hline \multirow{2}{*}{\multicolumn{4}{|c|}{ 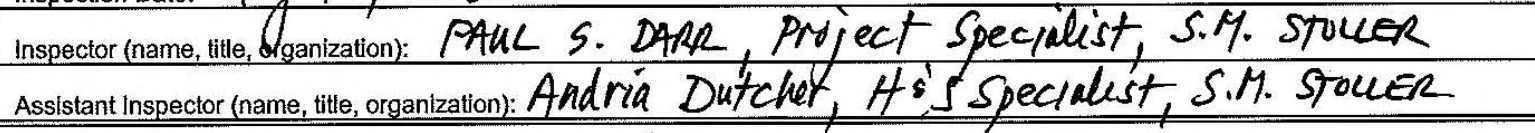 }} \\
\hline & & & \\
\hline \multirow{5}{*}{\multicolumn{4}{|c|}{$\begin{array}{l}\text { A. GENERAL INSTRUCTIONS } \\
\text { 1. All checklist items must be completed and detailed comments made to document the results of the site inspection. The completed } \\
\text { checklist is part of the field record of the inspection. Additional pages should be used as necessary to ensure that a complete } \\
\text { record is made. Attach the additional pages and number all pages upon completion of the inspection. } \\
\text { 3. Any checklist line item marked by an inspector in a SHADED BOX, must be fully explained or an appropriate reference to previous } \\
\text { reports provided. The purpose of this requirement is to provide a written explanation of inspector observations and the inspector's } \\
\text { rationale for conclusions and recommendations. Explanations are to be placed on additional attachments and cross-referenced } \\
\text { appropriately. Explanations, in addition to narrative, will take the form of sketches, measurements, annotated site maps. } \\
\text { 4. The site inspection is a walking inspection of the entire site including the perimeter and sufficient transects to be able to inspect the } \\
\text { entire surface and all features specifically described in this checklist. } \\
\text { 5. A standard set of color } 35 \text { mm photographs (or equivalent) is required. In addition, all anomalous features or new features (such } \\
\text { as changes in adjacent area land use) are to be photographed. A photo log entry will be made for each photograph taken. } \\
\text { 6. This unit will be inspected biannually with formal reporting to the Nevada Division of Environmental Protection to be done annually. } \\
\text { The annual report will include an executive summary, this inspection checklist with field notes and photo log attached, and } \\
\text { recommendations and conclusions. }\end{array}$}} \\
\hline & & & \\
\hline & & & \\
\hline & & & \\
\hline & & & \\
\hline B. PREPARATION (To be completed prior to site visit) & YES & NO & EXPLANATION \\
\hline \multicolumn{4}{|l|}{ 1. Site as-built plans and site base map reviewed. } \\
\hline \multirow{3}{*}{$\begin{array}{l}\text { 2. Previous inspection reports reviewed. } \\
\text { a. Were anomalies or trends detected on previous inspections? } \\
\text { b. Was maintenance performed? }\end{array}$} & $\checkmark$ & & \\
\hline & & & \\
\hline & & & \\
\hline \multirow{3}{*}{$\begin{array}{l}\text { 3. Site maintenance and repair records reviewed. } \\
\text { a. Has site repair resulted in a change from as-built conditions? } \\
\text { b. Are revised as-builts avallable that reflect repair changes? }\end{array}$} & $\checkmark$ & & \\
\hline & & & \\
\hline & & & $N / A$ \\
\hline C. SITE INSPECTION (To be completed during inspection) & YES & NO & EXPLANATION \\
\hline \multicolumn{4}{|l|}{ 1. Adjacent off-site features within watershed areas. } \\
\hline a. Have there been any changes in use of adjacent area? & & & \\
\hline b. Are there any new roads or trails? & & & \\
\hline c. Has there been a change in the position of nearby washes? & & & \\
\hline $\begin{array}{l}\text { d. Has there been lateral excursion or erosion/deposition of } \\
\text { nearby washes? }\end{array}$ & & & \\
\hline e. Are there new drainage channels? & & & \\
\hline f. Change in surrounding vegetation? & & & \\
\hline \multicolumn{4}{|l|}{ 2. Security fence, signs. } \\
\hline $\begin{array}{l}\text { a. Displacement of fences, site markers, boundary markers, or } \\
\text { monuments? }\end{array}$ & & & \\
\hline $\begin{array}{l}\text { b. Have any signs been damaged or removed? } \\
\text { (Number of signs replaced: } \quad \text { ) }\end{array}$ & & & \\
\hline c. Were gates locked? & & & \\
\hline
\end{tabular}




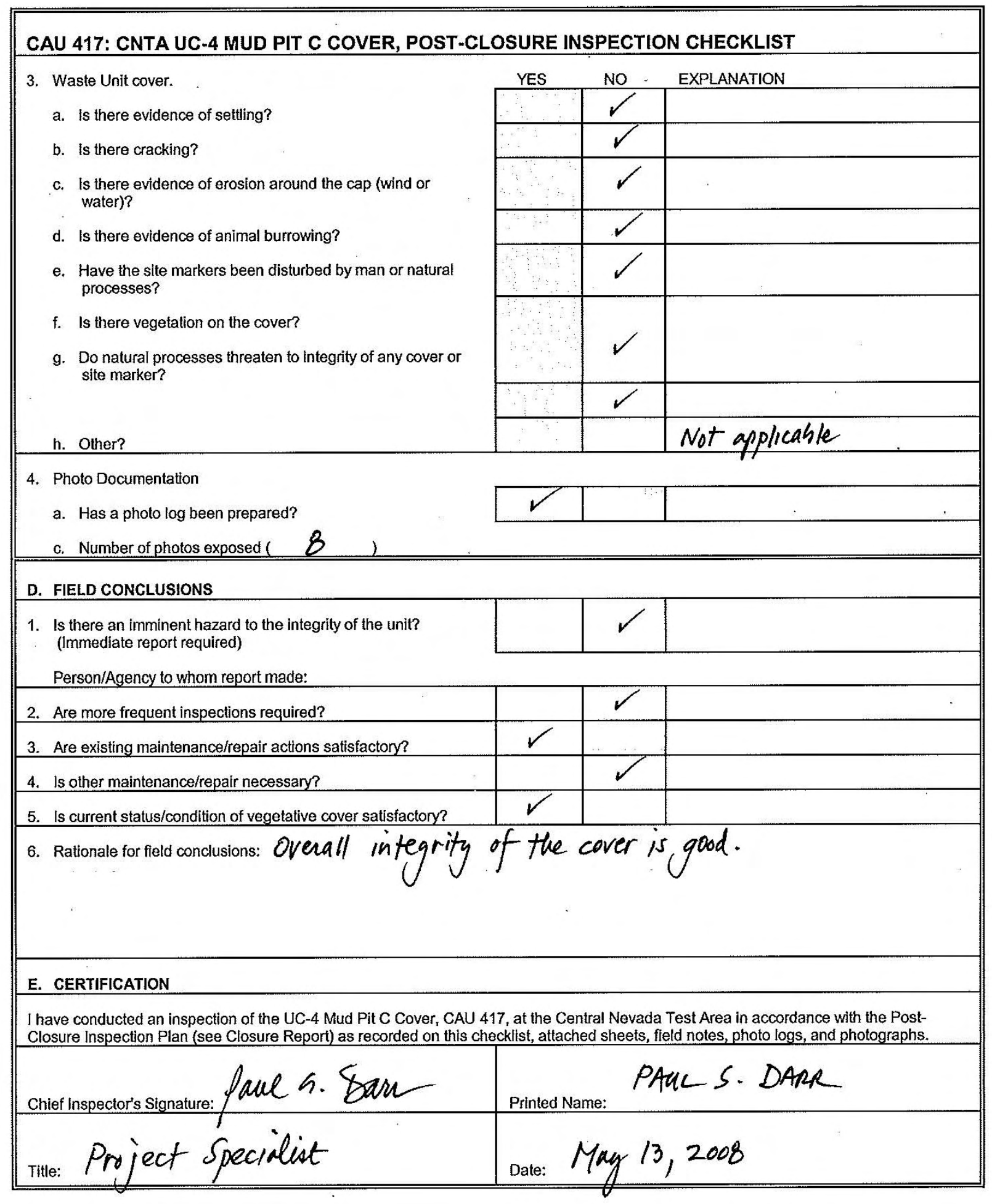




\section{Photograph Log}

\begin{tabular}{||c|c|l||}
\hline Photograph & Date & \multicolumn{1}{c||}{ Description } \\
\hline 1 & $05 / 13 / 2008$ & UC-1 View from south edge looking west \\
\hline 2 & $05 / 13 / 2008$ & UC-1 View from south edge looking northwest \\
\hline 3 & $05 / 13 / 2008$ & UC-1 View from south edge looking north \\
\hline 4 & $05 / 13 / 2008$ & UC-1 View from south edge looking northeast \\
\hline 5 & $05 / 13 / 2008$ & UC-1 Cover SM-9, SM-5, SM-1 \\
\hline 6 & $05 / 13 / 2008$ & UC-1 Cover SM-10, SM-6, SM-2 \\
\hline 7 & $05 / 13 / 2008$ & UC-1 Cover SM-11, SM-7, SM-3 \\
\hline 8 & $05 / 13 / 2008$ & UC-1 Cover SM-12, SM-8, SM-4 \\
\hline 9 & $05 / 13 / 2008$ & UC-1 Erosional rill east end of berm \\
\hline 10 & $05 / 13 / 2008$ & UC-4 View from center looking west \\
\hline 11 & $05 / 13 / 2008$ & UC-4 View from center looking east \\
\hline 12 & $05 / 13 / 2008$ & UC-4 View looking southeast \\
\hline 13 & $05 / 13 / 2008$ & UC-4 View looking northeast \\
\hline 14 & $05 / 13 / 2008$ & UC-4 View looking northwest \\
\hline 15 & $05 / 13 / 2008$ & UC-4 View looking southwest \\
\hline 16 & $05 / 13 / 2008$ & UC-4 View looking east from west subsidence marker \\
\hline 17 & $05 / 13 / 2008$ & UC-4 Cover overview \\
\hline
\end{tabular}


This page intentionally left blank 


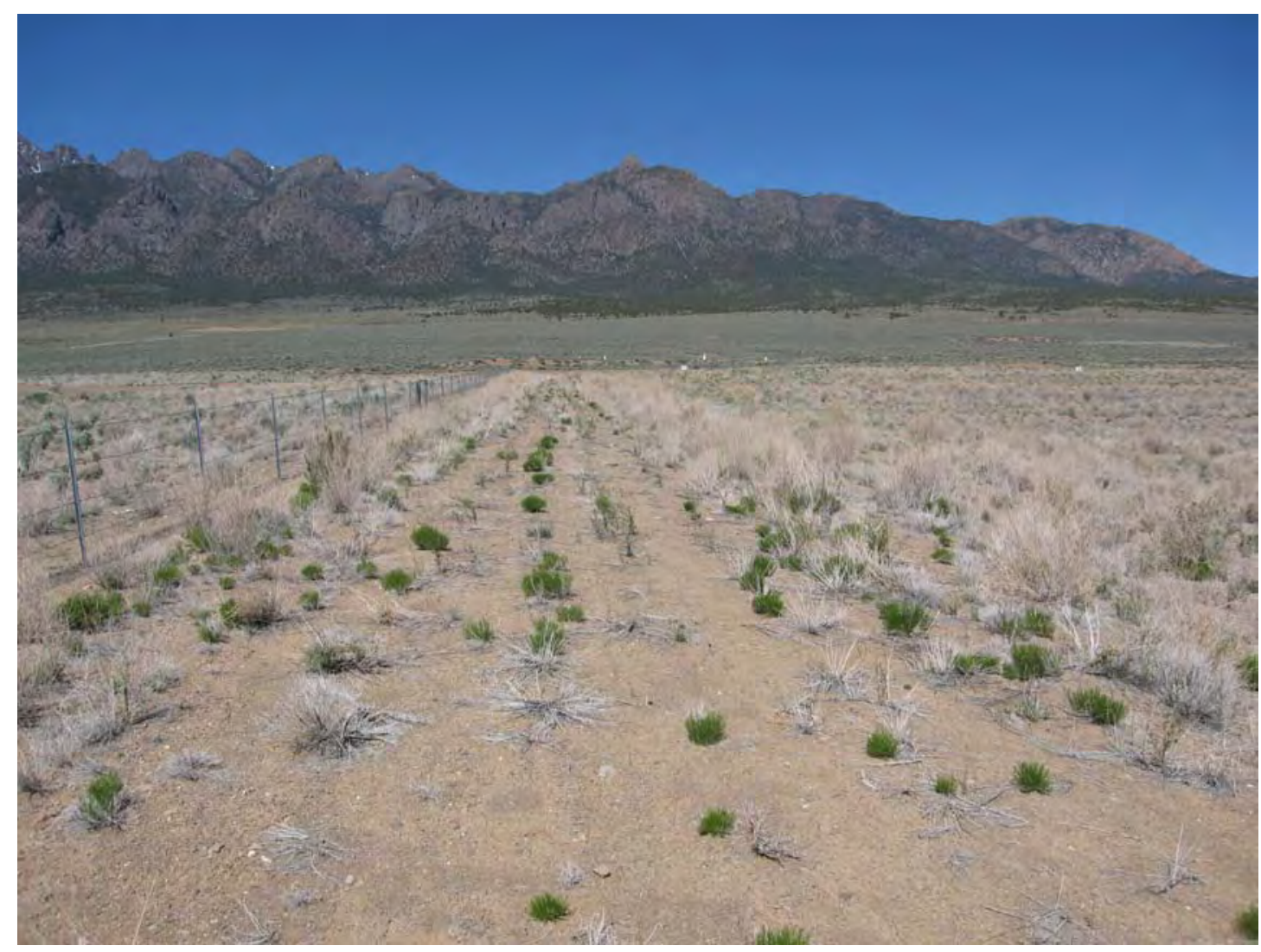

Photograph 1. UC-1 View from south edge looking west

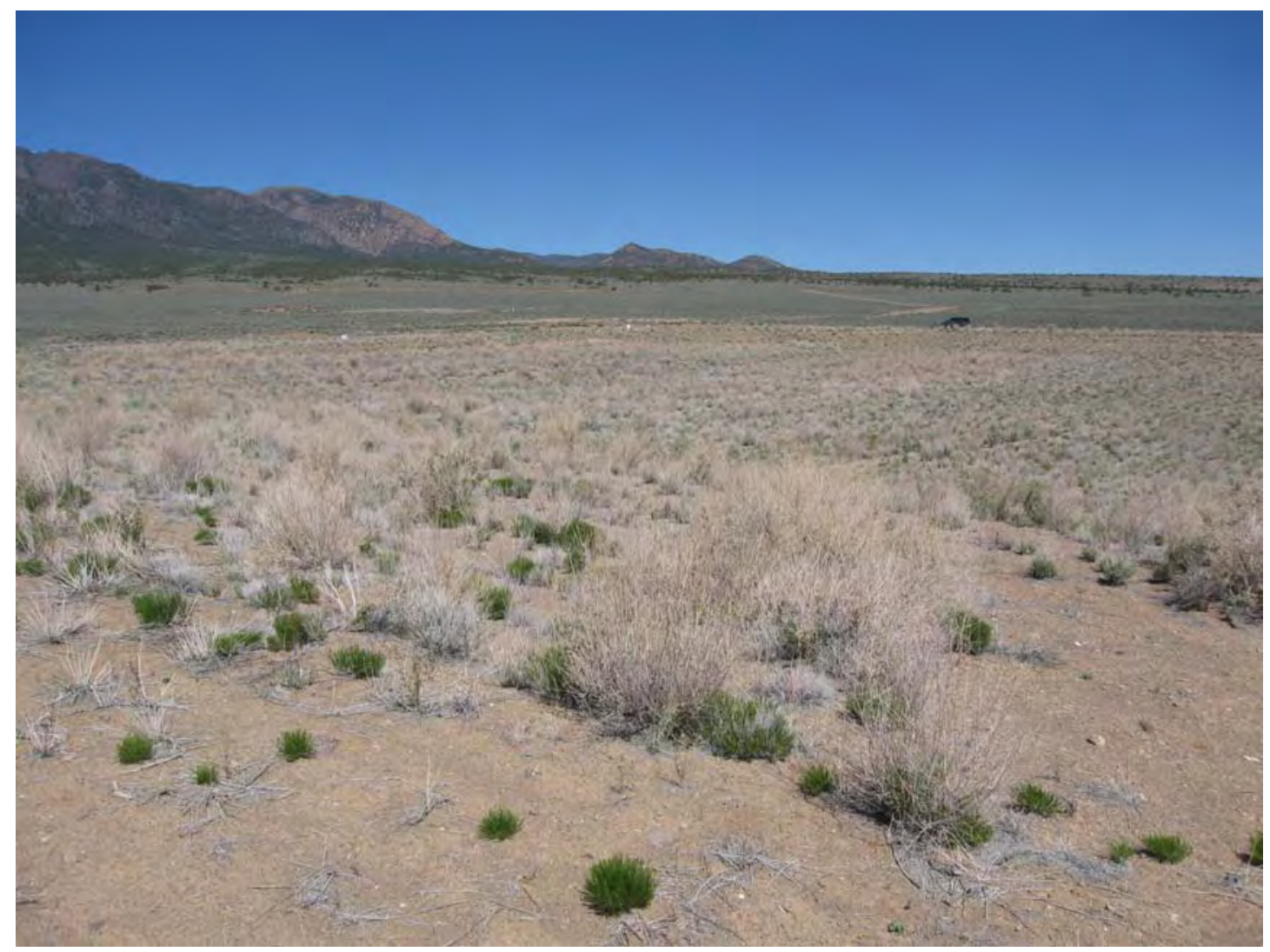

Photograph 2. UC-1 View from south edge looking northwest 


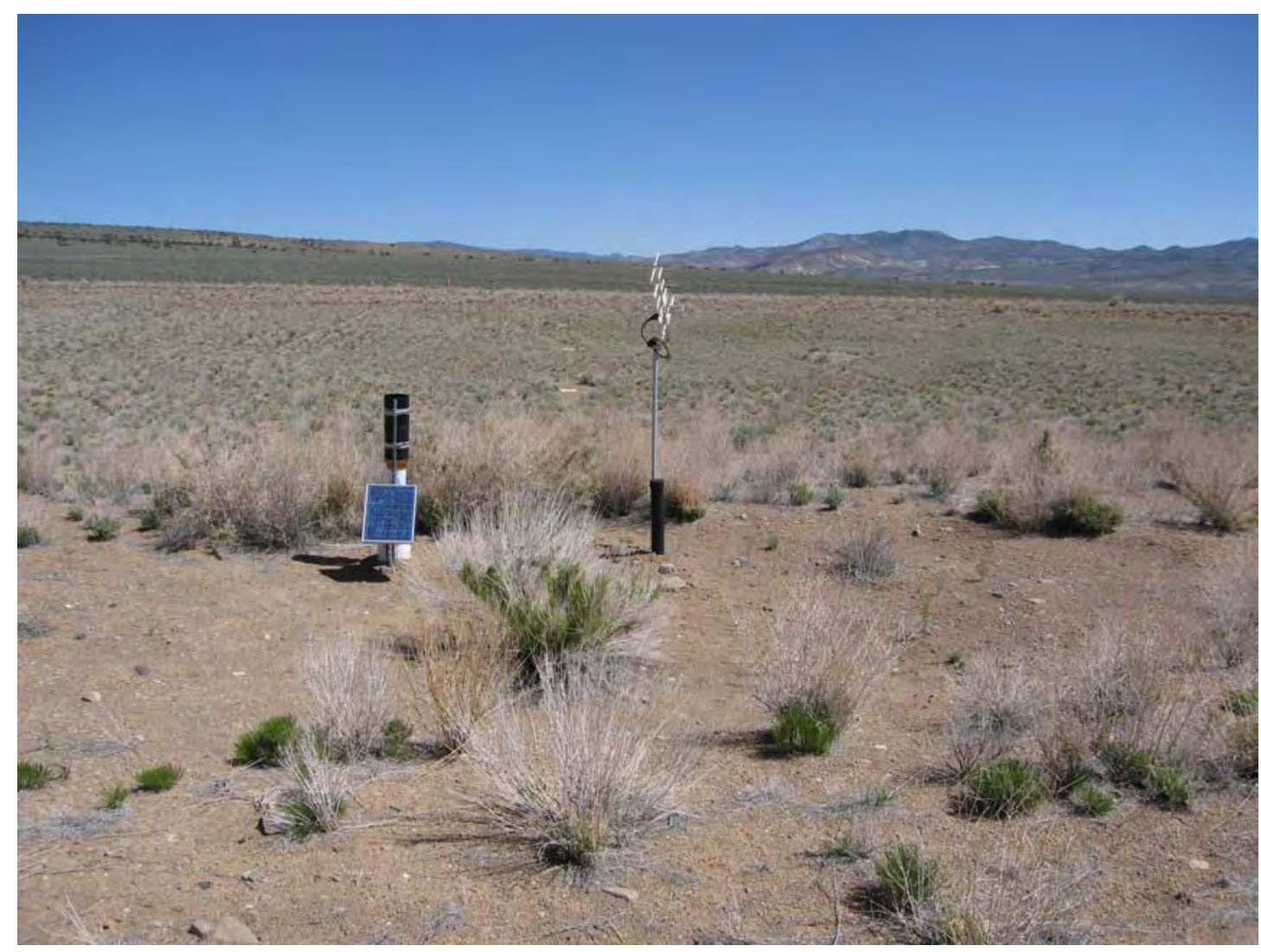

Photograph 3. UC-1 View from south edge looking north

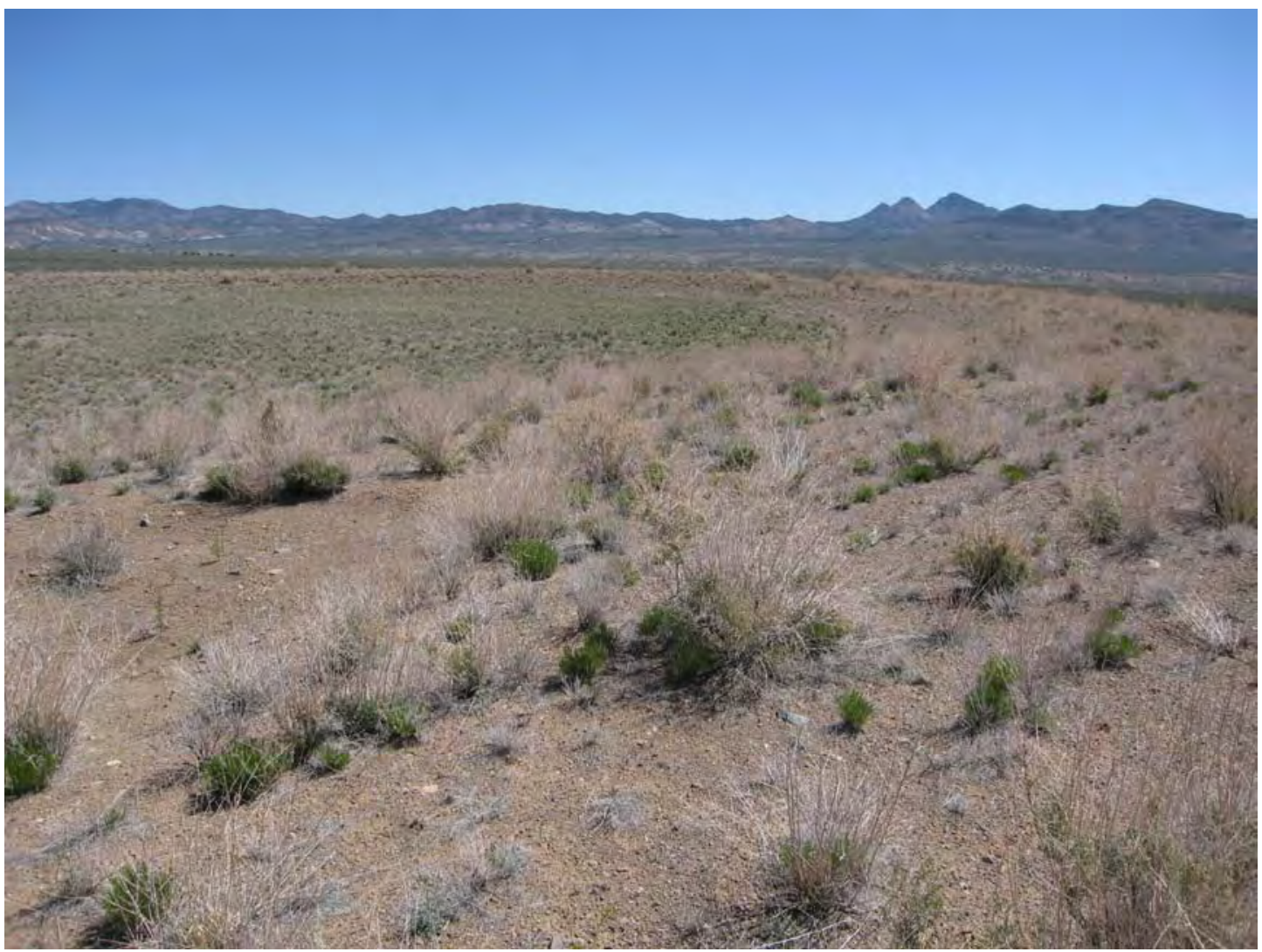

Photograph 4. UC-1 View from south edge looking northeast 


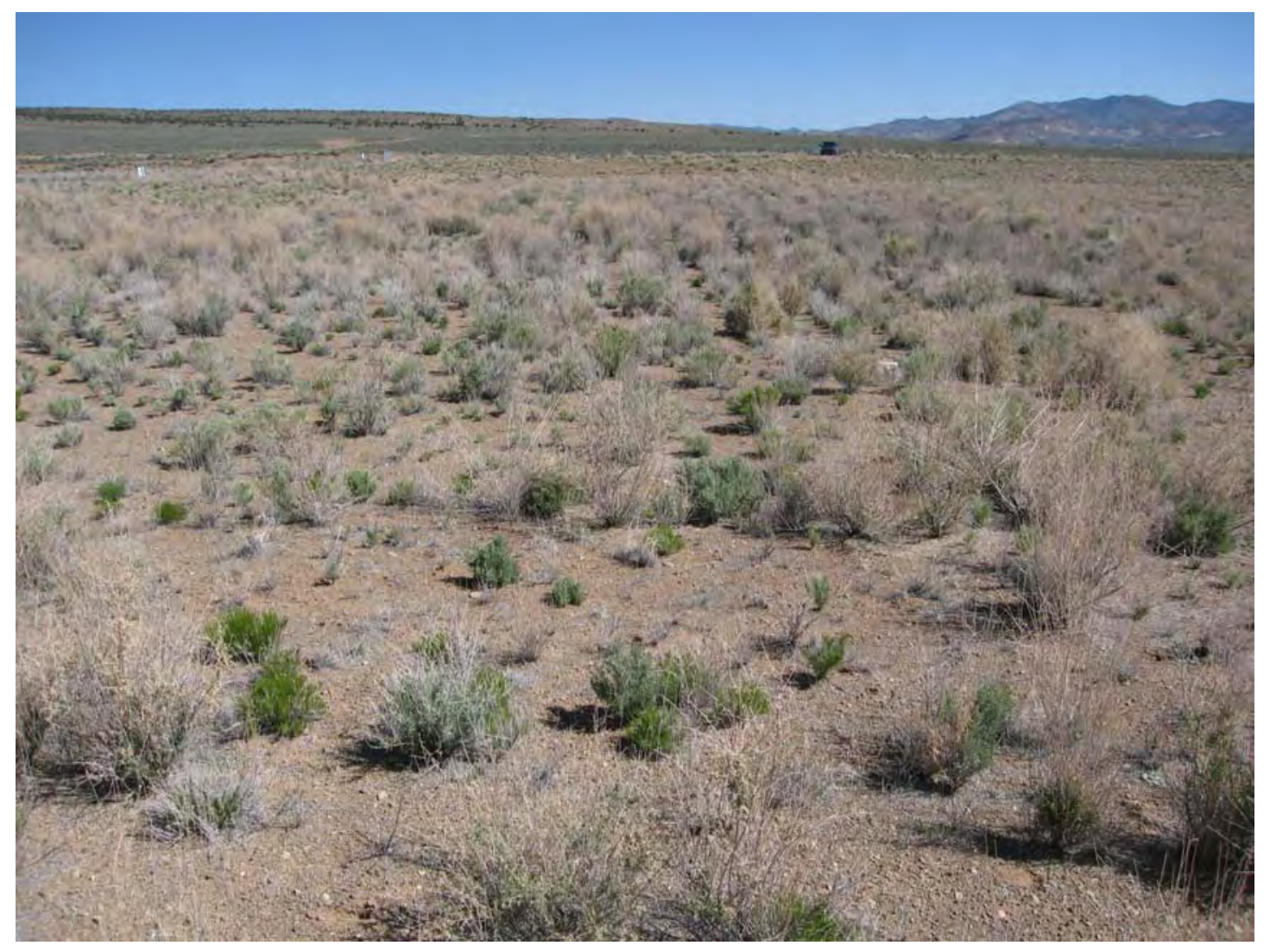

Photograph 5. UC-1 Cover SM-9, SM-5, SM-1

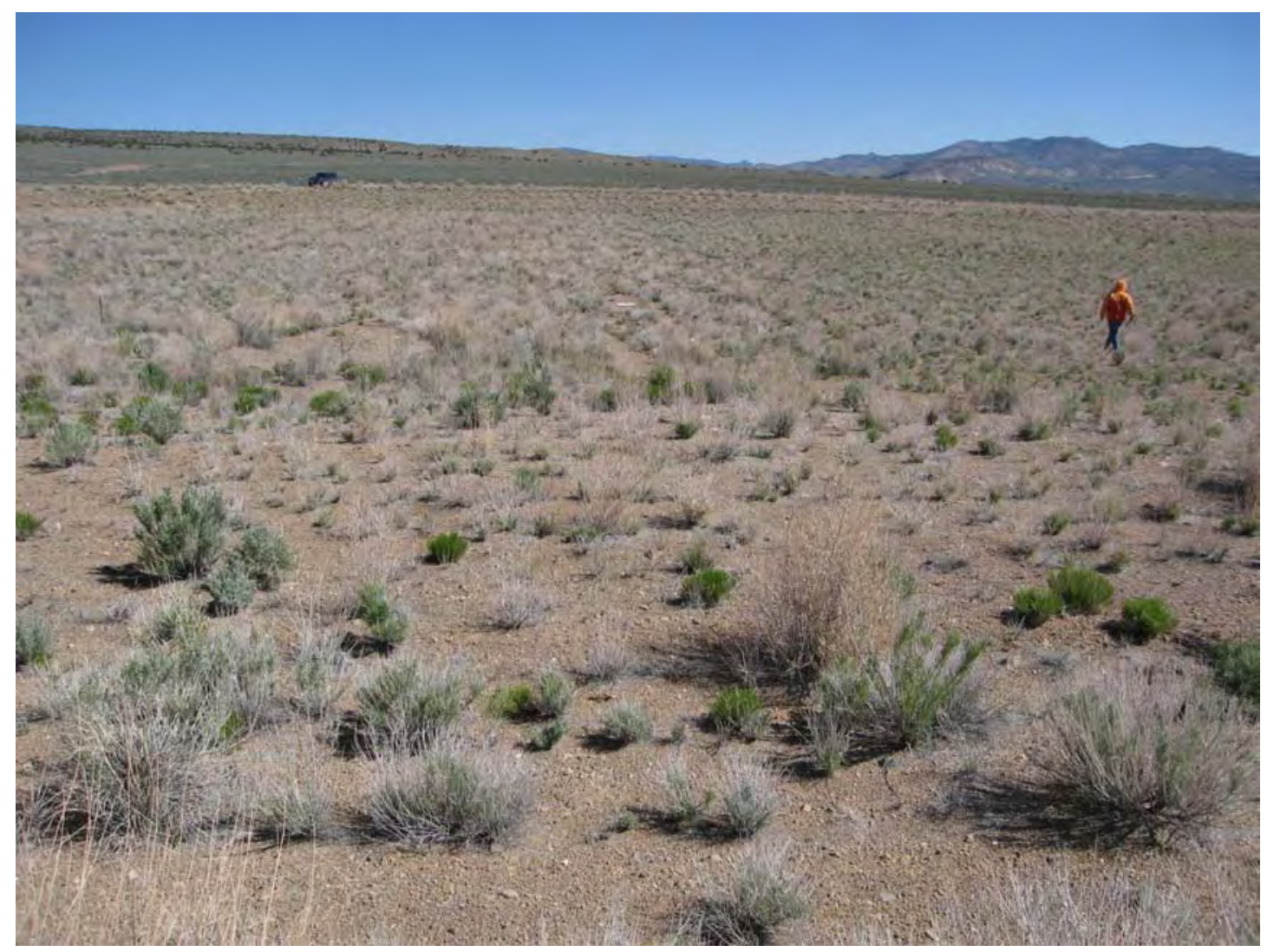

Photograph 6. UC-1 Cover SM-10, SM-6, SM-2 


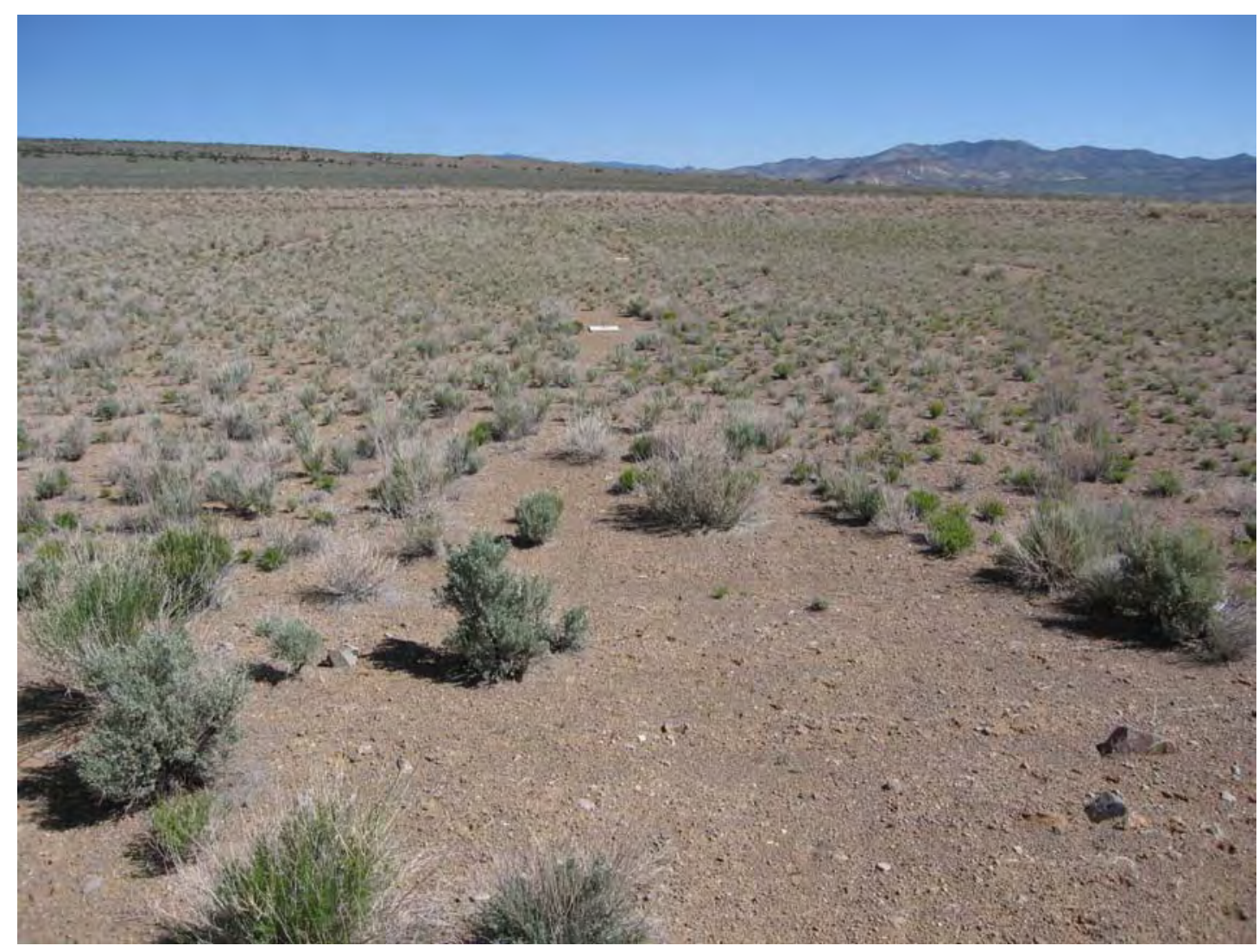

Photograph 7. UC-1 Cover SM-11, SM-7, SM-3

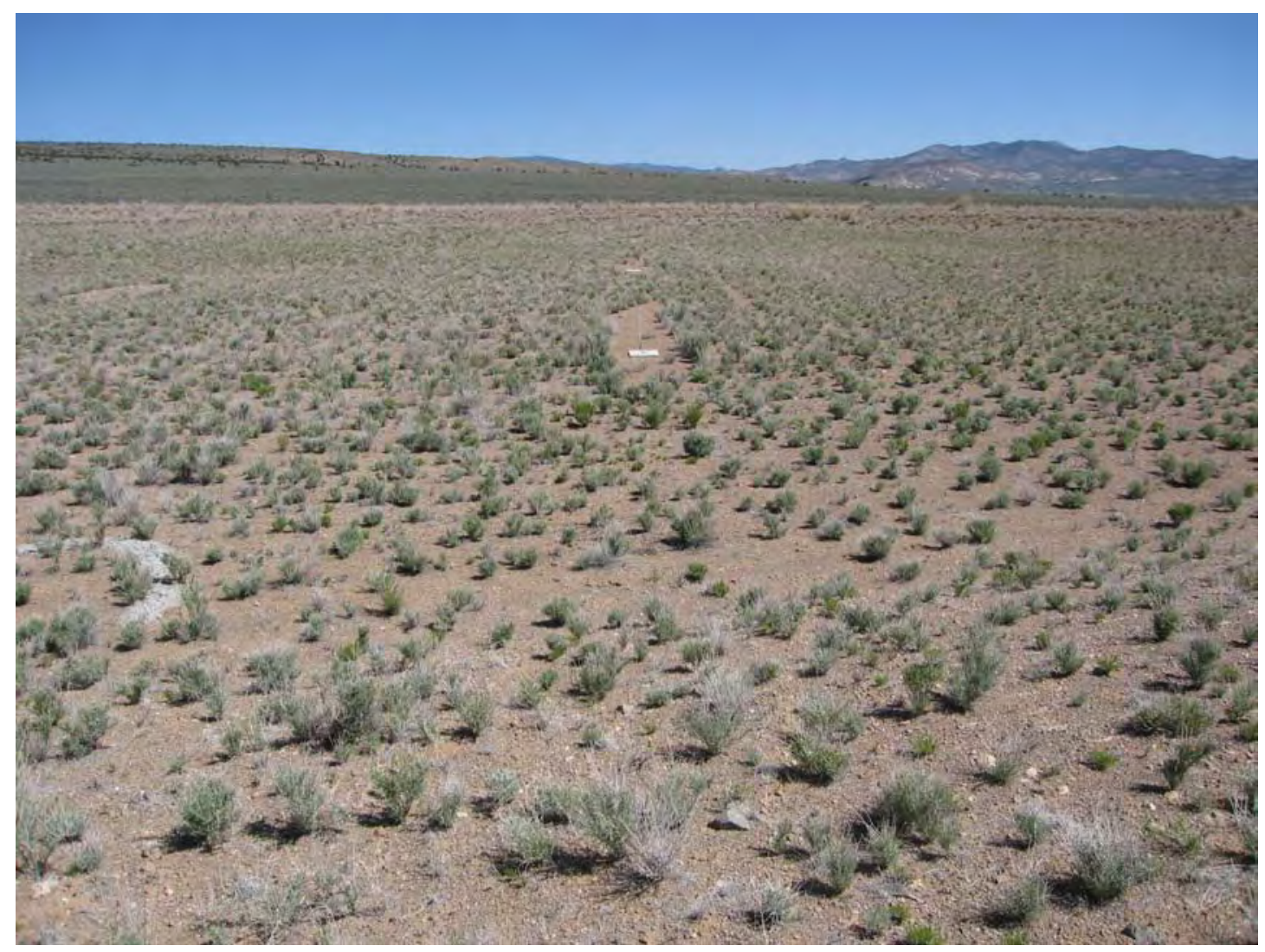

Photograph 8. UC-1 Cover SM-12, SM-8, SM-4 


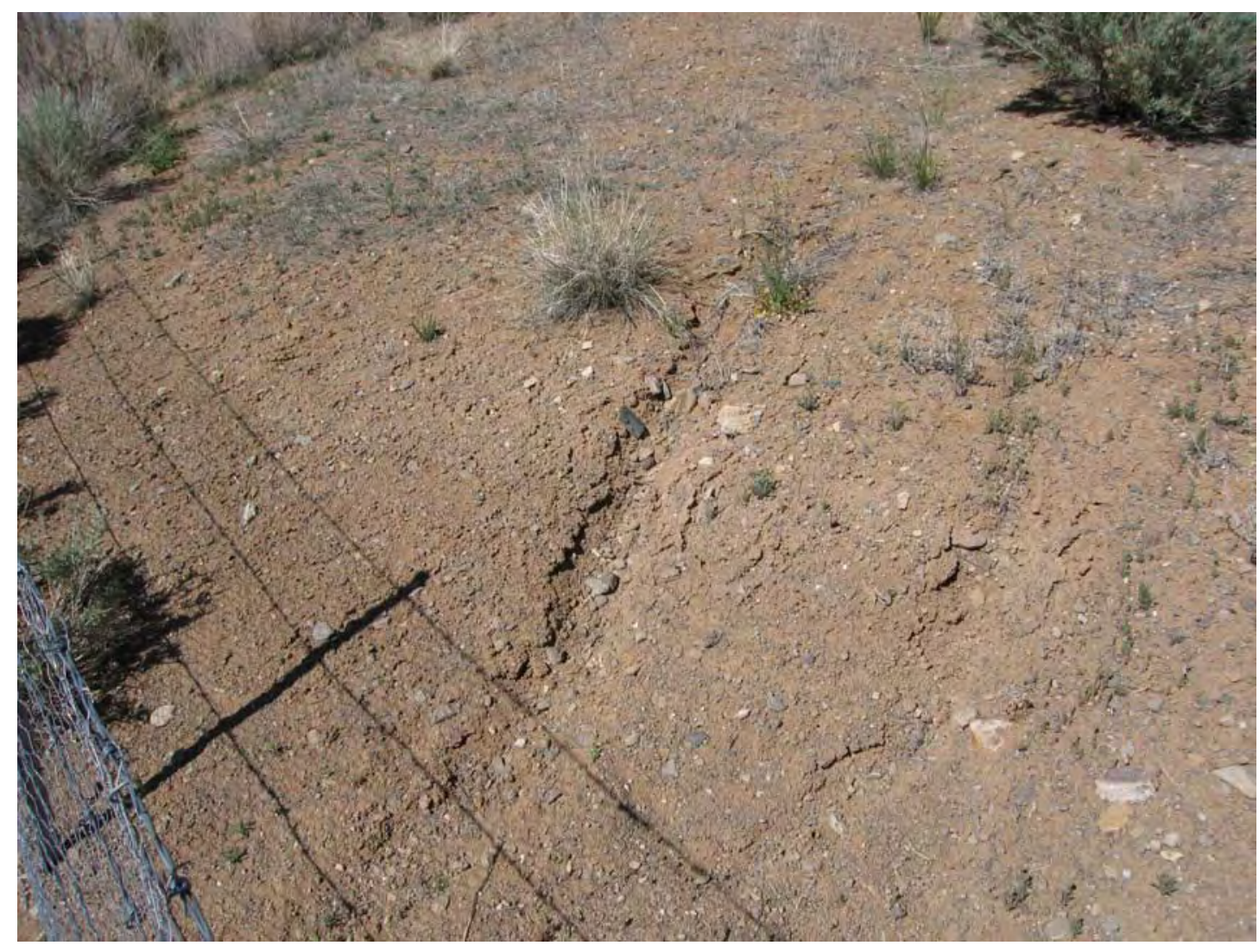

Photograph 9. UC-1 Erosional rill east end of berm

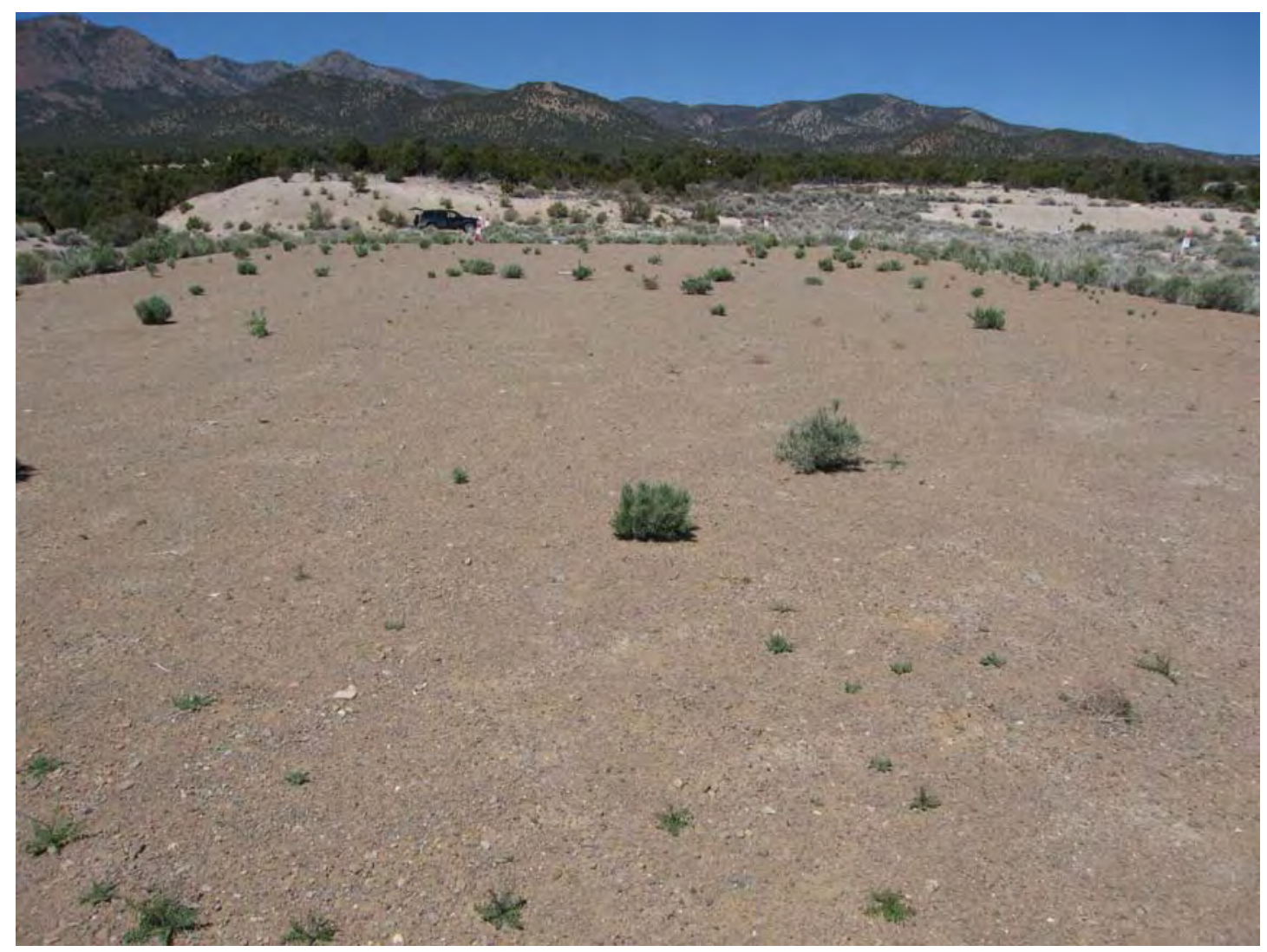

Photograph 10. UC-4 View from center looking west 


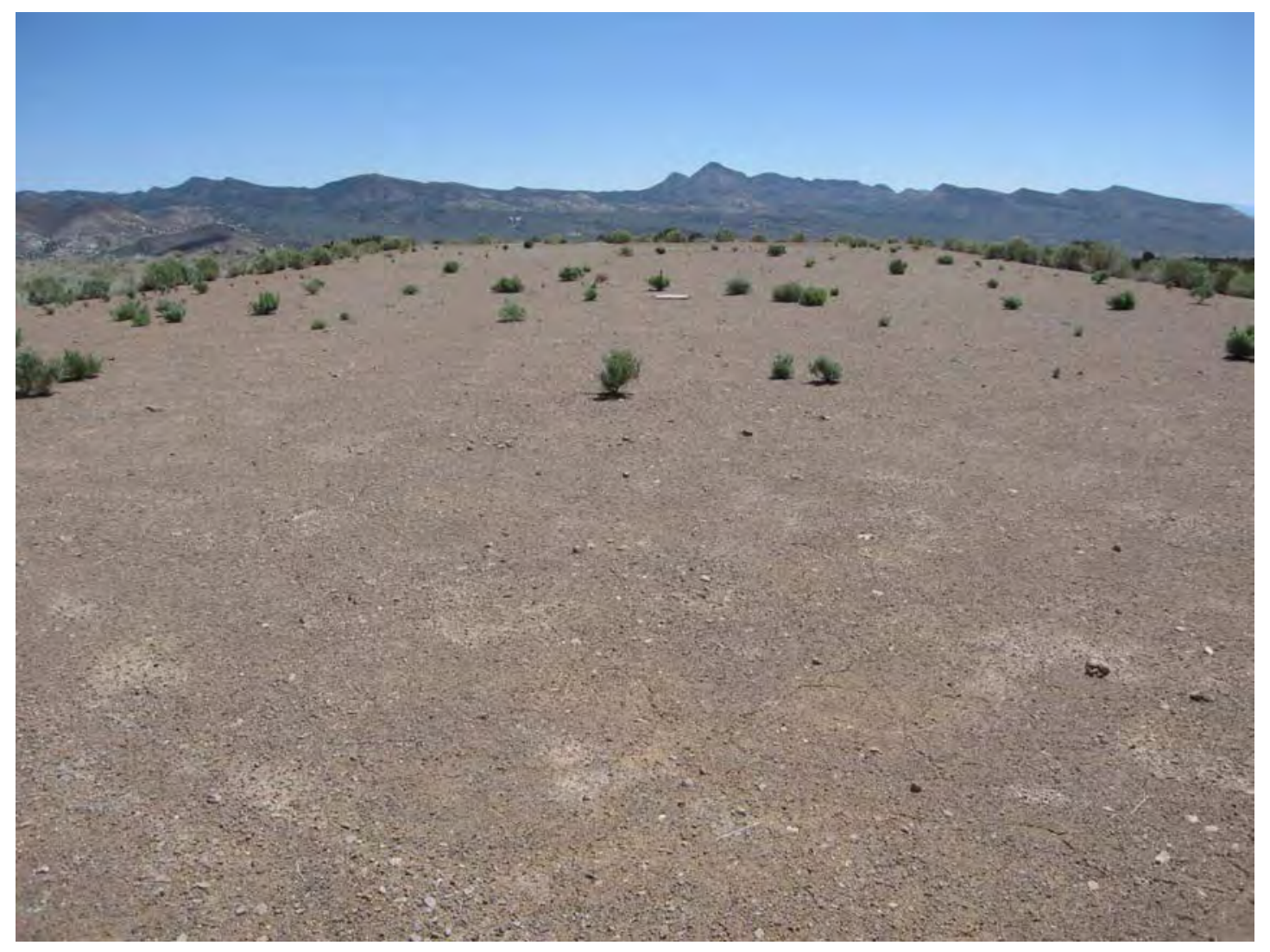

Photograph 11. UC-4 View from center looking east

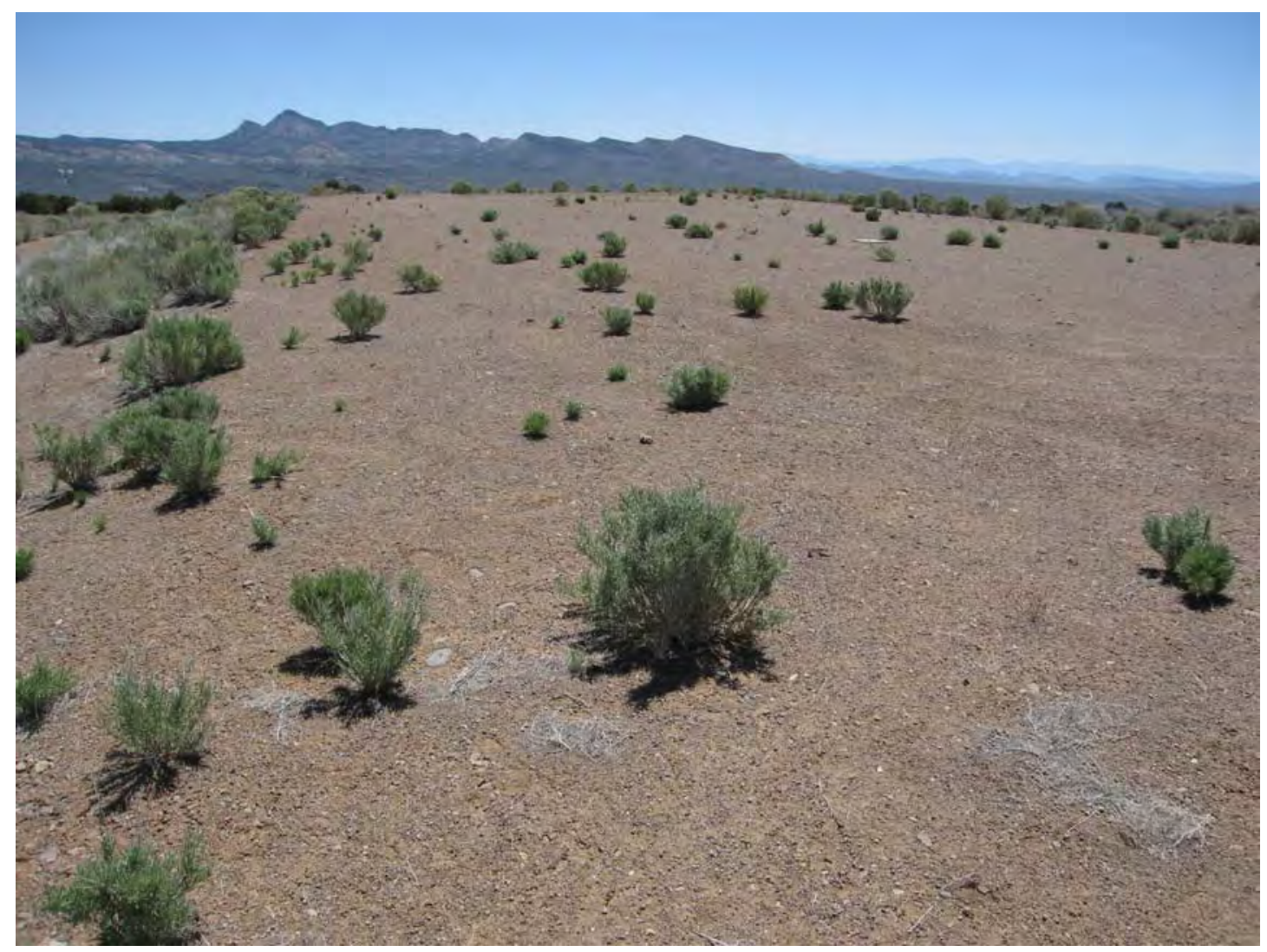

Photograph 12. UC-4 View looking southeast 


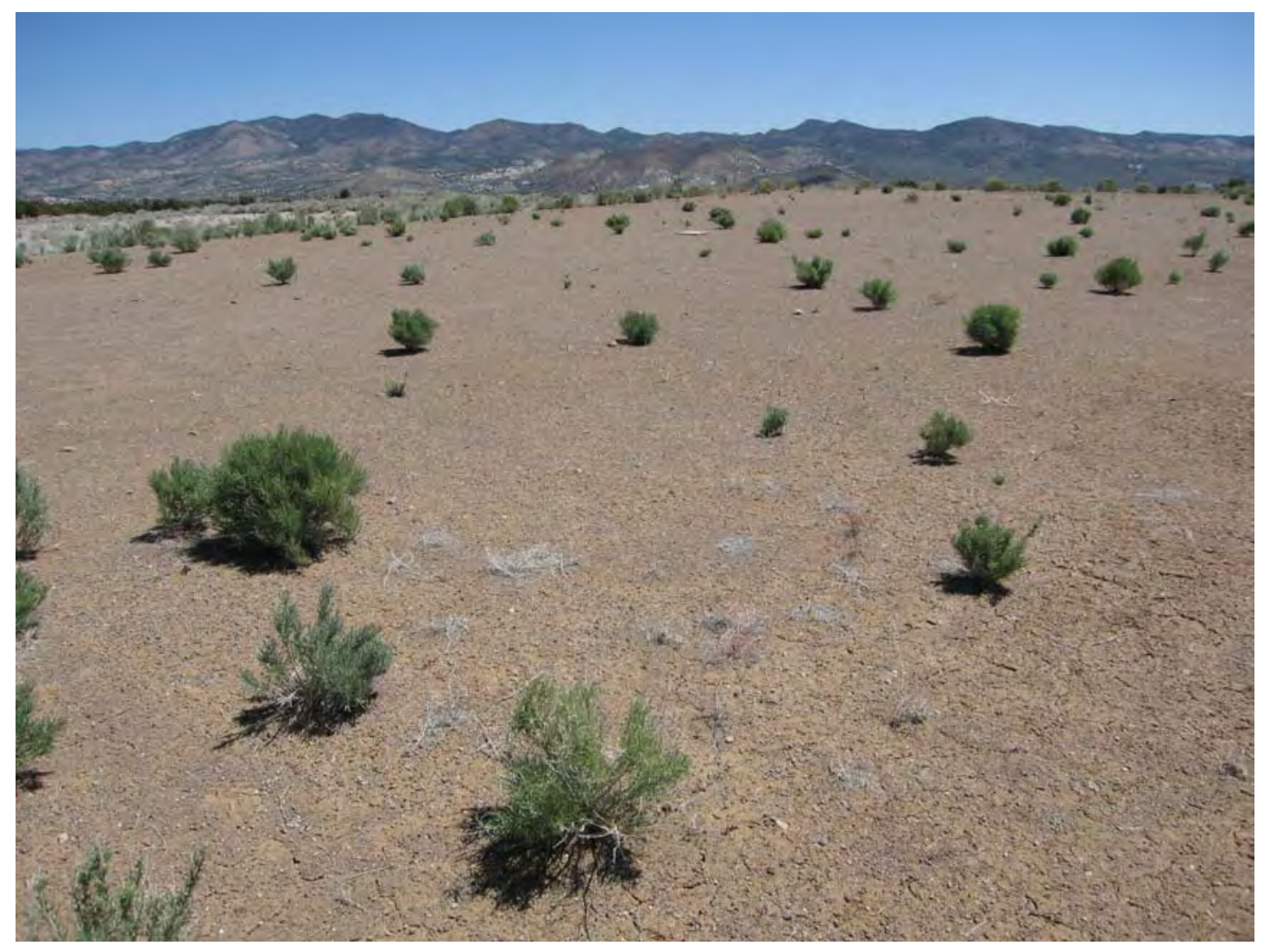

Photograph 13. UC-4 View looking northeast

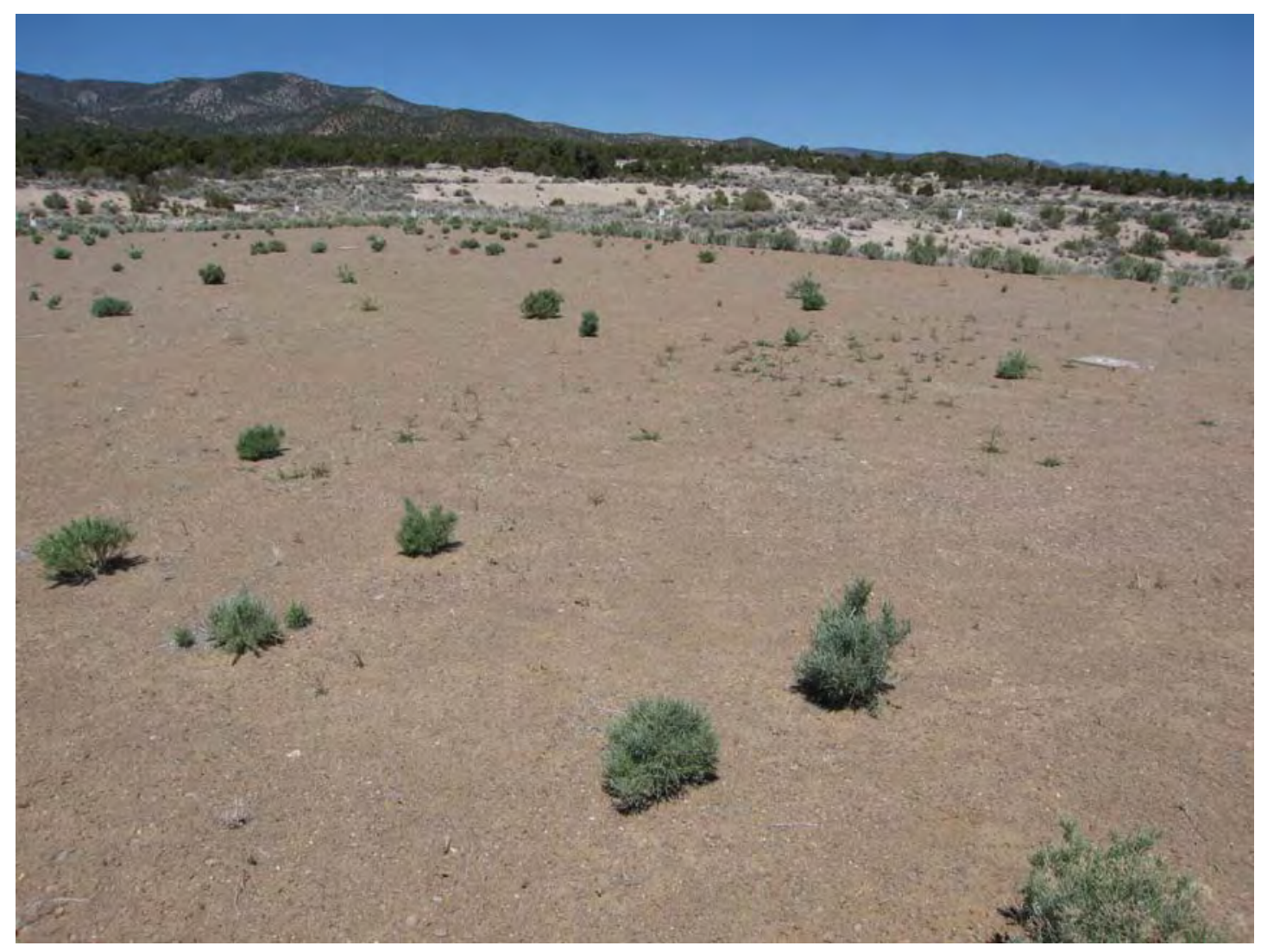

Photograph 14. UC-4 View looking northwest 


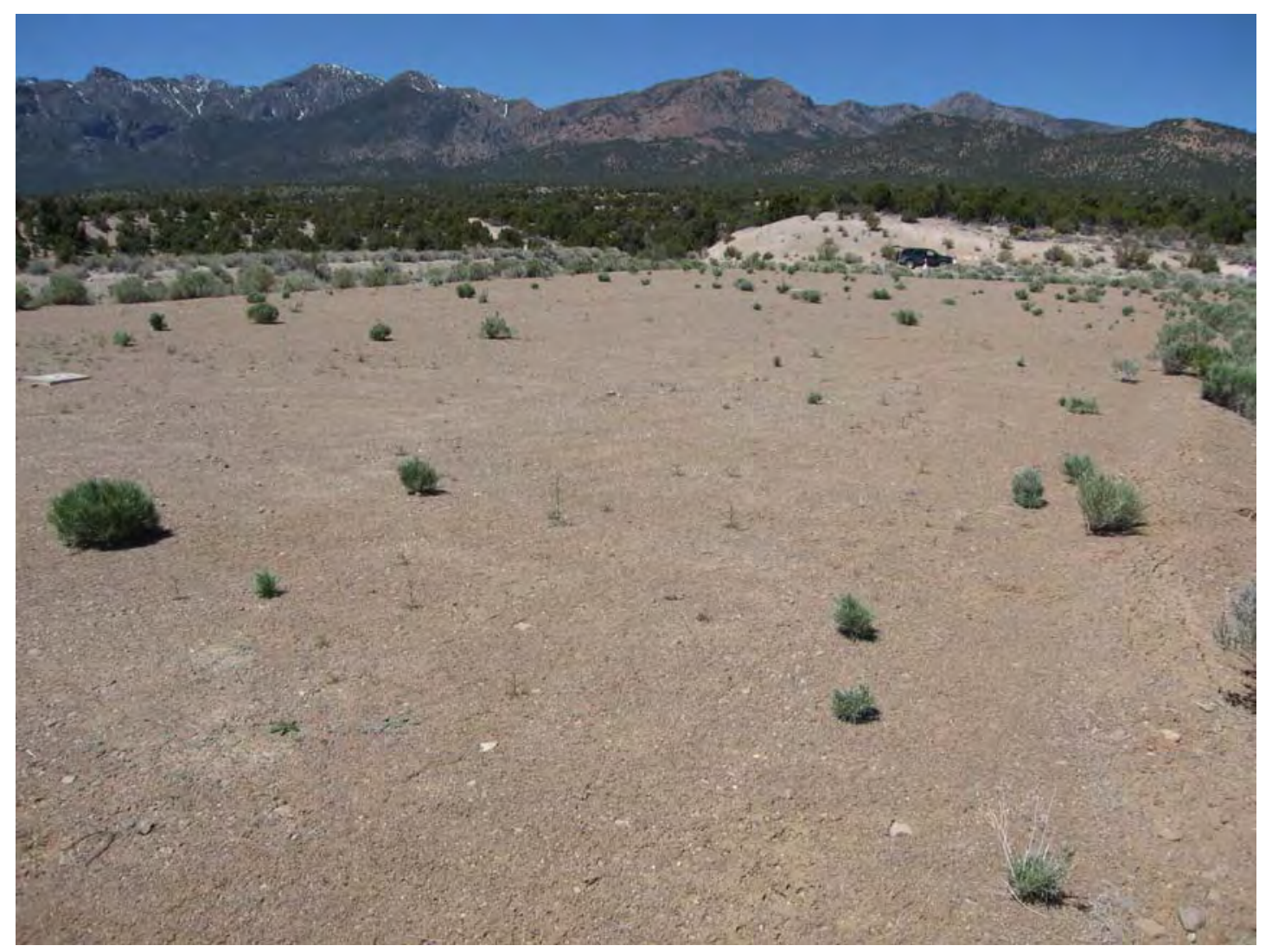

Photograph 15. UC-4 View looking southwest

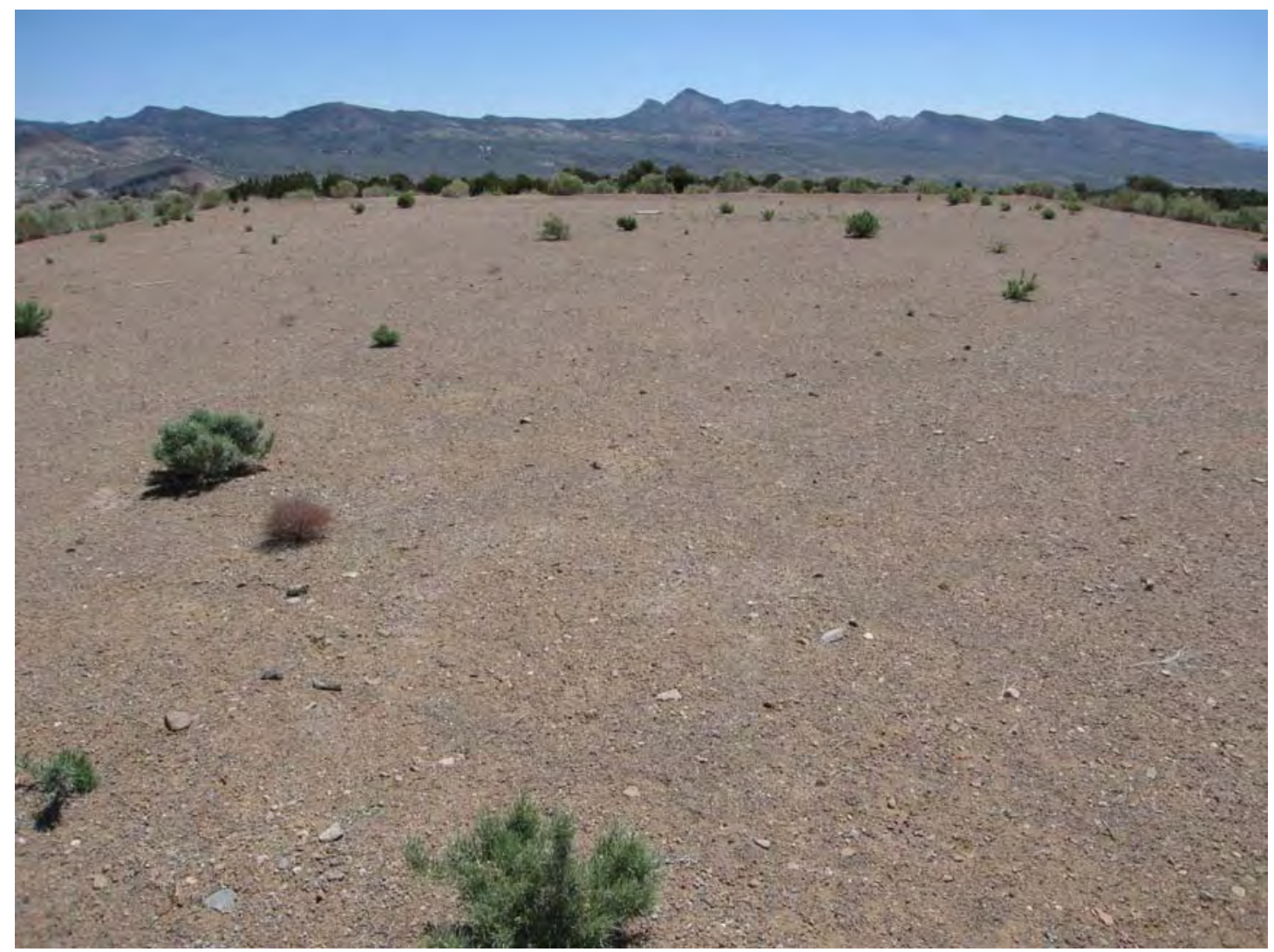

Photograph 16. UC-4 View looking east from west subsidence marker 


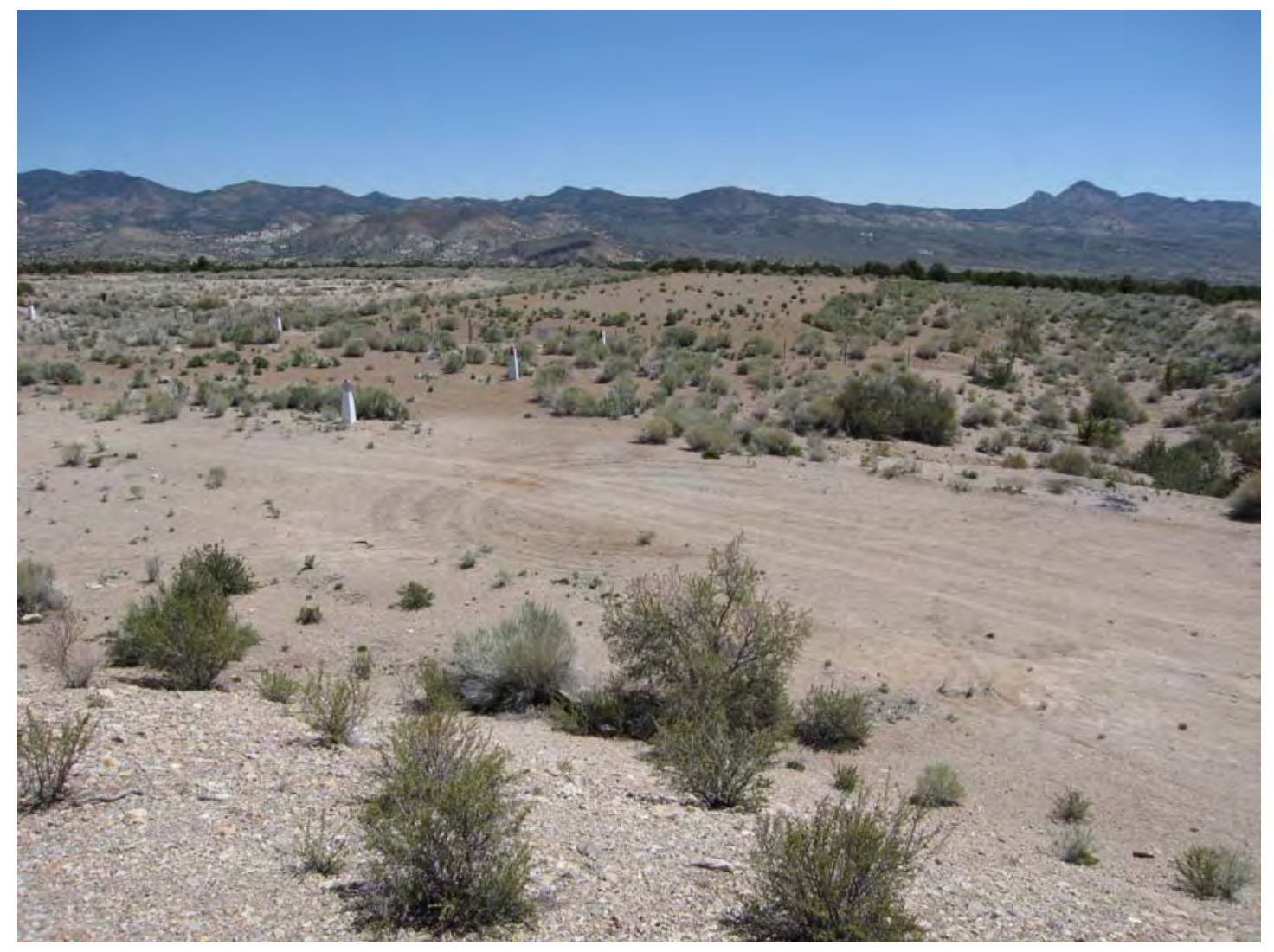

Photograph 17. UC-4 Cover overview 
This page intentionally left blank 
Appendix B

NDEP Correspondence 
This page intentionally left blank 


\section{STATE OF NEVADA}

Department of Conservation \& Natural Resources

Jim Gibbons, Governor

DIVISION OF ENVIRONMENTAL PROTECTION Allen Biaggi, Director

January 20, 2009

Mr. Mark Kautsky

Site Manager

U.S. Department of Energy

Office of Legacy Management

2597 B 3/4 Road

Grand Junction, CO 81503

RE: Post-Closure Inspection and Monitoring Report for Corrective Action Unit 417: Central Nevada Test Area Surface, Hot Creek Valley, Nevada December 2008

Federal Facility Agreement and Consent Order

Dear Mr. Kautsky:

The Nevada Division of Environmental Protection, Bureau of Federal Facilities (NDEP) staff has received and reviewed the above-referenced report on the post-closure inspection and monitoring activities conducted at the Central Nevada Test Area during calendar year 2008. The annual report was prepared in accordance with the Federal Facility Agreement and Consent Order (FFACO) and the Closure Report for Corrective Action Unit 417. The NDEP accepts this document as satisfying the annual reporting requirements and has the following comment/ question:

1. Figures 3-7, 3-9, 3-9 and 3-10 all show a volumetric moisture content increase around February 2008 but there is no precipitation indicated after September 2007. On Page 3-9, it is stated that the rain gauge was "repaired" during an October 2008 visit. Did the rain and/or snow gauge malfunction during February 2008? Why did the moisture content increase?

Please address any questions regarding this matter to Chris Andres at (702) 486-2850 ext. 232.

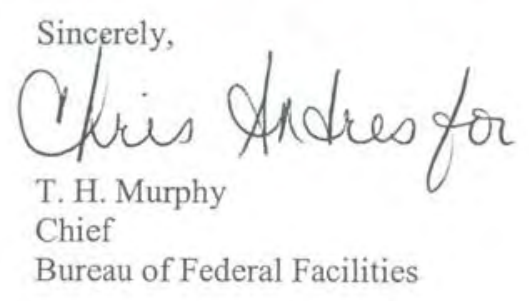

2030 E. Flamingo Road, Suite 230 • Las Vegas, Nevada 89119 •p: 702.486 .2850 •f: 702.486 .2863 • www.ndep.nv.gov printed on recpeled poper 
Mr. Robert Boehlecke

Page 2 of 2

January 20, 2009

$\mathrm{TM} / \mathrm{MM} / \mathrm{EAJ} / \mathrm{CDA}: \mathrm{cda}$

cc: Kevin Cabble, ERP, NNSA/NSO, Las Vegas, NV

J. B. Chapman, DRI, Las Vegas, NV

D. Crawford, Stoller, Grand Junction, CO

E. F. DiSanza, WMP, NNSA/NSO, Las Vegas, NV

FFACO Group, SNJV, Las Vegas, NV

R. Findlay, Stoller, Grand Junction, CO

Jeffrey Fraher, DTRA/CXTS, Kirtland AFB, NM

W. R. Griffin, SNJV/DTRA, MS 645, Mercury, NV

R. Hutton, Stoller, Grand Junction, CO

NSTec Technical Information Officer, Las Vegas, NV 


\section{Library Distribution List}

\section{$\underline{\text { Copies }}$}

U.S. Department of Energy

1 (Uncontrolled)

National Nuclear Security Administration

Nevada Site Office

Technical Library

P.O. Box 98518, M/S 505

Las Vegas, NV 89193-8518

702-295-3521

U.S. Department of Energy

1 (Uncontrolled, electronic copy)

Office of Scientific and Technical Information

P.O. Box 62

Oak Ridge, TN 37831-0062

865-576-8401

Southern Nevada Public Reading Facility

2 (Uncontrolled, electronic copies)

c/o Nuclear Testing Archive

P.O. Box 98521, M/S 400

Las Vegas, NV 89193-8521

Manager, Northern Nevada FFACO

Public Reading Facility

1 (Uncontrolled, electronic copy)

c/o Nevada State Library \& Archives

100 N Stewart Street

Carson City, NV 89701-4285

775-684-3313

Librarian

Churchill County Library

1 (Uncontrolled)

553 South Main

Fallon, NV 89406

775-423-7581

Librarian

Tonopah Public Library

167 Central Street

Tonopah, NV 89049

775-482-3374

1 (Uncontrolled) 
This page intentionally left blank 